\title{
PUTTING YAR RGYAB ON THE MAP
}

\author{
MATHIAS FERMER ${ }^{1}$ \\ (IKGA, Austrian Academy of Sciences)
}

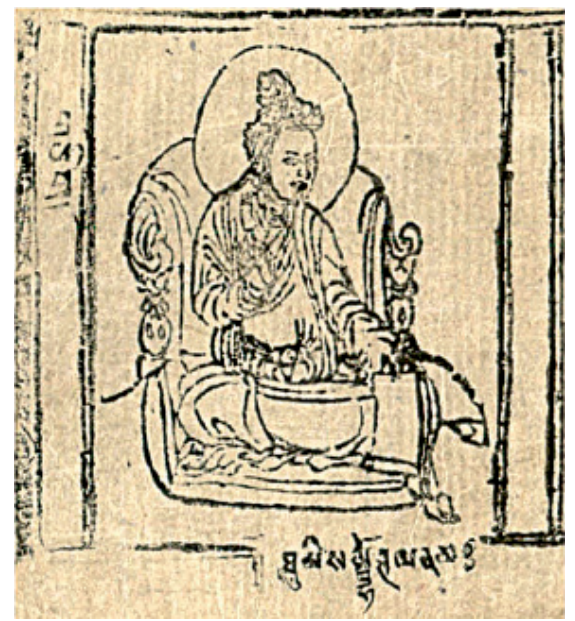

Fig. 1: Thu mi Sam bho ța, front-page illustration of xylograph, biography of Gong dkar rdo rje gdan pa Kun dga' rnam rgyal (1432-1496), fol. 1v left end.

A particularly vital role in the religious dynamics and cultural achievements of fifteenth-century Lhokha (lHo kha) was played by the Yar rgyab regional ruling house, a powerful family that was a major political force in Central Tibet (dBus gtsang) from the late fourteenth century through the fifteenth century. Members of this family backed some of the greatest Buddhist masters of the time and supported

1 I am very grateful to the editors of these proceedings for allowing me to substantially revise my paper before its publication. My research on this topic was generously funded by the Austrian Science Fund (FWF): F42 Visions of Community. I would like to thank my doctoral advisor Guntram Hazod (ISA, Austrian Academy of Sciences, Vienna) as well as David Jackson (Washington) for corrections and valuable comments on this paper. I would also like to thank my colleagues Tsering Drongshar, Reinier Langelaar and Cynthia Peck-Kubaczek from the Institute for the Cultural and Intellectual History of Asia (IKGA, Austrian Academy of Sciences, Vienna) for their language support, and Jörg Heimbel (University of Hamburg) for providing me with a recent study on the Yar rgyab pa that appeared in last year's first issue of Bod ljongs zhib 'jug. 
large-scale religious projects in their realm. Under their rule, several monastic communities were established, communities whose respective teaching traditions then flourished. In major histories and local biographies of the late fifteenth and early sixteenth centuries, the Yar rgyab rulers are vividly remembered as illustrious patrons of the Buddha's teaching (bstan pa'i sbyin bdag) and its contemporary teachers.

Seeking blessings, spiritual guidance and advice, the ruling family invited religious leaders associated with various teaching lineages to their court, pleasing them with offerings and provisions. The available biographies of lamas who sojourned for shorter or longer periods in the Yar rgyab dominion describe the support they received and how the ruling family provided (sbyar) them with favourable conditions (mthun [pa'i] rkyen, 'thun ; bdag rkyen) for beneficent activities and the propagation of Buddhist teachings. This included support for hosting religious events, rituals or prayer services, as well as spiritual instruction for the royal court or the public. The visiting lamas were entrusted with directing large projects funded by the local Yar rgyab court, including the founding or renovating of monastic institutions and temples, the maintenance of religious communities, and the manufacture of receptacles representing the Buddha's body, speech and mind (rten gsum; i.e. statues, scriptures and stüpas). The sources moreover tell us that the ruling family encouraged and backed visiting lamas to pursue their own practices and scriptural training, to travel and to compose or translate texts. Not only acting as generous hosts for lamas visiting their realm, the ruling family members also granted them assistance for teaching, study, pilgrimage and worship beyond the boundaries of Yar rgyab.

This paper draws on the lifestories (rnam [par] thar [pa]; lit. "liberated [deeds]") of a handful of such masters, lamas who received substantial patronage from the Yar rgyab ruling house. Their lives are retold by direct disciples or themself and depict its protagonists in a closely-knit religious network that developed around the court. Based on information from these lifestories together with in situ toponym investigations, ${ }^{2}$ this paper delineates the Yar rgyab family's sphere of influence in the fifteenth century, identifying the main sites and agents connected to their support and financial backing.

\section{The Historical Context}

In Tibetan history, the period in question falls into the hegemonial rule of two rival powers in Central Tibet: the Rlangs Phag mo gru pa (r. 1354-ca. 1480/90s) from dBus Province, and the Rin spungs pa (r. ca. 1480/90s-1565) based in gTsang Province. With the gradual decline of the Yuan dynasty in the middle of the fourteenth century, the Phag mo gru pa replaced the Mongol-backed Sa skya administration as

2 On the methodology of combining text analysis with ethnological fieldwork for the study of Tibetan historical geography, cf. Hazod 2010. 
overlords of Tibet. Under Ta'i si tu Byang chub rgyal mtshan (1302-1364), the first ruler of the Phag mo gru dynasty, the secular power shifted from Sa skya in western gTsang to the Yar lung valley in the southern part of dBus. For the next decades, Tibet's central provinces (i.e. dBus and gTsang) were administered by the Rlangs ruling family, with their power base at sNe gdong palace in Lower Yar lung. After the reign of the fifth Phag mo gru pa ruler, Gong ma Grags pa rgyal mtshan (d. 1432), members of the Rin spungs family who had served the Phag mo gru pa as regional officers in gTsang began to challenge their overlords. Gradually, through alliances and military exploits, the noble family in charge of the Rin spungs estate (gZhis kha Rin spungs) extended its influence and gained control over large territories in gTsang and dBus. By around the 1480s, the officers of Rin spungs controlled large parts of Central Tibet, and eventually took the political authority from the Phag mo gru government, although the nominal administration of the country remained in their hands at sNe gdong (var. sNe'u gdong). ${ }^{3}$ The struggle between these two family dynasties for transregional dominance naturally involved other ruling houses and the monastic communities under their protection. Thus, throughout the fifteenth century Tibet's central regions experienced a disturbing period (dus [g]zings; dus 'khrug[s]) of political turmoil and military conflict. This is occasionally reflected in the histories and biographies of the time.

\section{The Lineage Affiliation of Yar rgyab}

During the successive dynasties of the Phag mo gru pa and the Rin spungs pa, the noble family known as the Yar rgyab pa ruled a central part of southern dBus, dispersed today over several districts of modern Lhokha Prefecture (Ch. Shānnán dìqū). These regional lords traced their genealogical origins back to the time of the Tibetan empire, claiming descent from Srong btsan sgam po's (d. 649/650) famous minister Thon mi Sam bho ta (see fig. 1). Minister Thon mi (or Thu mi) is one of the most eminent figures in Tibetan history, remembered as the inventor of a script for the Tibetan people, a great grammarian and the first Tibetan to receive the title of translator (lo tsa $\bar{a}$ ba; 'jig rten gyi mig). ${ }^{4}$ The paternal line of the Yar rgyab pa back to the legendary inventor of the Tibetan script can be reconstructed from a passage in the annals of the Fifth Dalai Lama, as well as from genealogical sketches in the extant biographies of two fifteenth-century masters who were members of the Yar rgyab family, Byams pa gling pa bSod nams rnam rgyal (1400-1475), also widely known by the epithets Byams pa gling pa and Byams gling pan chen, and his disciple Gong

3 For a detailed overview of these events, see Czaja 2013: chap. 5, "The Rlangs Phag mo gru pa during the $15^{\text {th }}$ Century," 207-246; bSod nams grags pa, New Red Annals: 214-228; Ahmad 1995: 151-157.

4 For the question of the historicity of Thon mi Sam bho ța, see van Schaik 2011. 
dkar rdo rje gdan pa Kun dga' rnam rgyal (1432-1496). ${ }^{5}$ These biographies provide short sketches of the family line originating from Thon mi (thu'i gdung, thon rigs or thon mi'i gdung rgyud) to which they belonged. Apart from the condensed information given here, the history of this ruling house, including its myth of origin and its first place of dwelling, as well as the circumstances that led to its rise to power in southern dBus, are largely unknown. ${ }^{6}$ Apparently lost are two Yar rgyab family genealogical chronicles (gdung rabs). One of these, the Genealogy of the Yargyabpa (Yar rgyab pa'i gdung rabs), authored by Byams pa gling pa himself, was later consulted by the Fifth Dalai Lama. ${ }^{7}$ Another lost family chronicle was written by the Yar rgyab ruler Ngag dbang kun dga' bsod nams rgyal po (fl. late $15^{\text {th }}$ or first half of the $16^{\text {th }}$ cent.), counted as the seventeenth in the paternal family line, a work known as the Extended Genealogy of the Thumi Lineage (Thu'i gdung rabs rgyas pa). This lengthy genealogy is mentioned in the hagiography of the Yar rgyab scion Gong dkar Kun dga' rnam rgyal following a brief chronology of his ancestors back to the imperial minister Thon $\mathrm{mi}^{8}$

5 Ahmad 1995: 180f.; Byang chub rnam rgyal, Jampalingpa Biography: 3b1-5a7; Byang chub dbang rgyal, Gongkarwa Biography I: 14-16.

6 The geographic origin of the Thon/Thu family in either gNyal (var. dMyal) to the southeast of Yar lung in Lhokha and/or in sNye mo of the present-day municipal district of Lhasa (Ch. Lāsà shì) is addressed in several academic and modern Tibetan publications. See, inter alia, Sørensen 1994: 167f. n. 462; dGe slong Blo bzang don ldan 1982: 3-6; U yon lhan khang (ed.) 2000: 25-27, 54f.; Nor brang o rgyan 2006: 182-186; Yangs gling rdo rje 2003: 312-321; g.Yu gra bsod tshe 2016: 14f. Guntram Hazod locates Thon mi's birthplace to the east of present-day 1Hun rtse County (Ch. Lōngzǐ xiàn) in gNyal, at a site today called "Thonmi Sambhota"; see Burial Mounds of Central Tibet, site no. \#0075, http://www.oeaw.ac.at/tibetantumulustradition/ sites_by_id/0075/ (accessed: 2016-11-02). dGe slong Blo bzang don ldan, a native of Thon mda' in sNye mo, sketches the territory under the Thon pa chiefs who were based in sNye mo (apparently during the dGa' ldan pho brang administration); cf. Thon mi sam bho ta' $i$ rnam thar, p. 7: thon pa sde dpon gyi sa mtshams/ yar rgyab thon pa shar du khri zam yar rgyab rtsa ba'i sa thob sa mtshams nub tu stod kyi ri dmar po zhes ngam ring gi gtsag thon sa byang du phra leb zhes pa nag tshang shan rtsa rdzong khongs kyi sa lho phyogs rdo gru bzhi zhes pa do rdzong sa khongs kyi rdo gru bzhi chen po zhig yod skad. I am indebted to Tashi Tsering (Amnye Machen Institute, Dharamsala) for this reference.

7 Ahmad 1995: 162. In addition to the lost genealogy, bSod nams rnam rgyal also presented his family lineage in a register, authored on the occasion of an extensive copying of sütras and the erecting of a rNam rgyal stūpa at rGyal chen gling estate to fulfill the last wishes of the deceased Yar rgyab queen $\mathrm{Bu}$ 'dren dpal [mo]; cf. rGyal chen gling gi 'bum chen dkar chag: 2a6-3a7. bSod nams rnam rgyal compiled this text of six folios in the year 1430 (iron-dog) at the palace of lHun grub gling in Grwa phyi; cf. ibid.: 6b6. I am very grateful to Tashi Tsering (Amnye Machen Institute, Dharamsala), who provided me a copy of this rare source. Byams pa gling pa's biography also mentions this text and quotes part of the colophon; cf. Byang chub rnam rgyal, Jampalingpa Biography: 18a1-3.

8 Byang chub dbang rgyal, Gongkarwa Biography I: 16. 


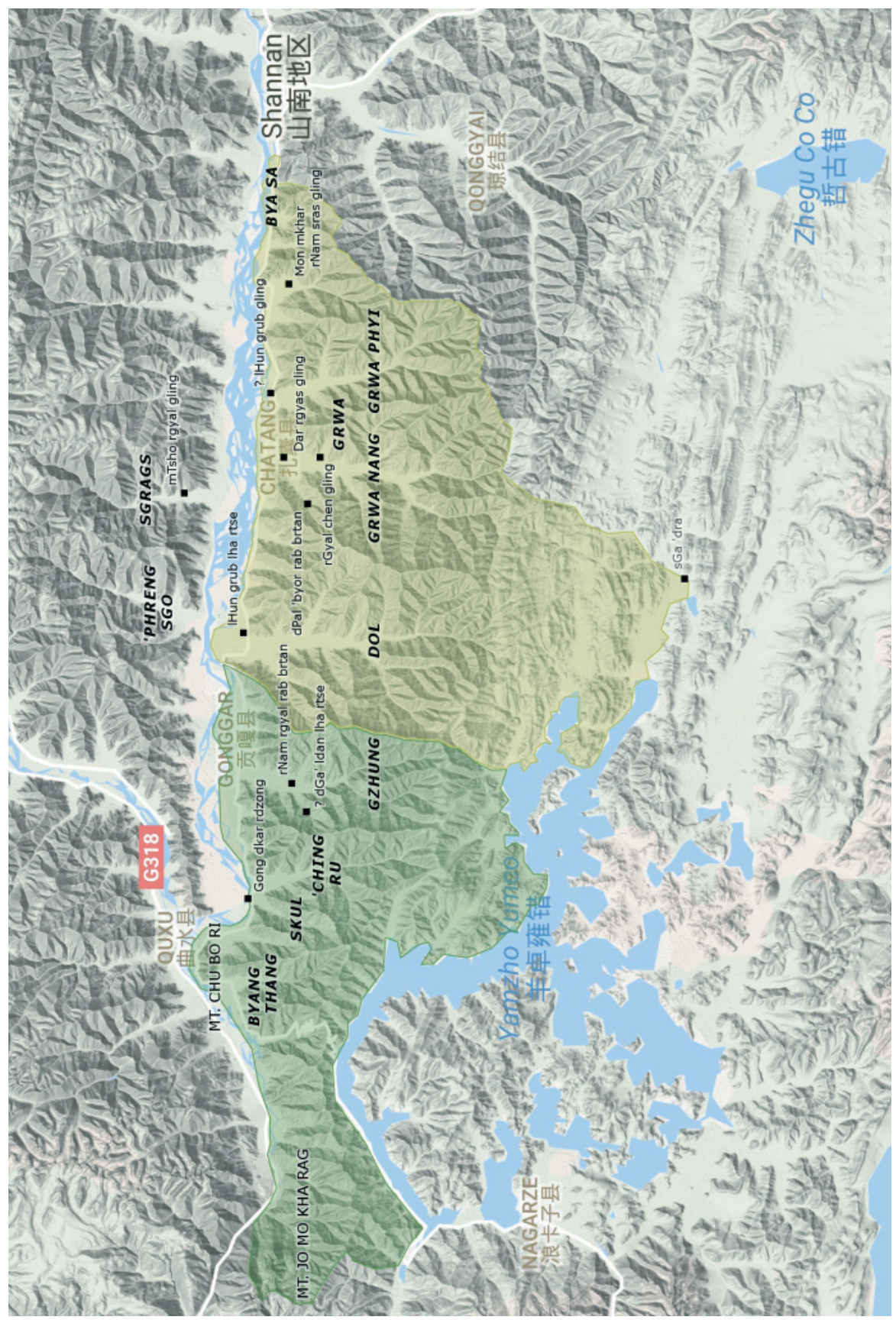

Fig. 2: Approximate expanse and estate holdings of the greater Yar rgyab family realm according to Byams pa gling pa's lifestory, with the Gong dkar and Yar rgyab districts green and yellow, respectively (based on Google My Maps; Map data 2016 Google). 
Gong dkar rdo rje gdan pa Kun dga' rnam rgyal, under his pre-monastic name Grwa lnga rgyal po, held positions as the head officer of Yar rgyab (1444-1446) and then Gong dkar (1446-1460s/70s) before eventually taking full ordination from his teacher Byams pa gling pa. ${ }^{9} \mathrm{He}$ is also known by the epithet Gong dkar ba, having been the head of Gong dkar and the founder of the district's largest monastery, opposite from where he had formerly wielded power. Since the time of his grandfather, the Yar rgyab pa had controlled a central region of southern dBus constituting two principalities under the central government of the Phag mo gru pa. ${ }^{10}$ The associated offices reserved for his family were that of the Gong dkar District Officer ( $g$ ong dkar rdzong dpon) and the Great Officer of Yar rgyab (yar rgyab dpon chen). The portrayal of the Yar rgyab ruling house in the lifestories of Gong dkar ba and his teacher Byams pa gling pa both reveal that the sNe gdong rulers had appointed candidates for the offices at Gong dkar and Yar rgyab from among Yar rgyab family members for at least four successive generations. ${ }^{11}$

\section{Rise and Territory}

The lifestory of Byams pa gling pa was compiled by 1Cags ri ba Byang chub rnam rgyal (b. ca. 1420) in the fire-horse year 1486. In addition to briefly describing the family's past achievements, the author explicitly sketches the expanse of the family domain at the time of his writing. He concludes the section on his master's genealogical background with a geographic delineation of the territory under the Yar rgyab pa, stating: "The complete southern ranges [stretching] from Bya sa yar rgyab up to Jo mo kha rag are governed (bdag po mdzad pa) by the brothers [of the Yar rgyab family]. Up to the present day [their power] has increased more and more."12 According to his description, the domain under the Yar rgyab rulers stretched from Bya sa in the east to Mount Jo mo kha rag in the west, a point that traditionally demarks the border between the dBus and gTsang provinces. As in this passage, Yar

9 For his early life as a secular ruler, see Byang chub dbang rgyal, Gongkarwa Biography I: 24f. See also Byang chub rnam rgyal, Jampalingpa Biography: 31a5-7; Jackson 1983: 11. Gong dkar Kun dga' rnam rgyal took the vows of a fully ordained monk (dge slong: bhiksu) in the year 1474 (wood-horse) at his monastic seat Gong dkar rdo rje gdan; see Byang chub dbang rgyal, Gongkarwa Biography I: 29-31; Byang chub rnam rgyal, Jampalingpa Biography: 68ab.

10 This is evident from bSod nams grags pa's lists of the regional officers under the successive Phag mo gru pa rulers; see New Red Annals: 217, 221, 224, 225.

11 For the family members prior to the fourteenth century, see the references in note 5 above. Other family members of the fourteenth and fifteenth centuries appear in the biographies mentioned here and will be addressed in the course of this article.

12 Byang chub rnam rgyal, Jampalingpa Biography, f. 5a2-3: 'dor (=mdor) na bya sa yar rgyab nas/ jo mo kha rag man gyi lho brgyud thams cad kyi bdag po sku mched rnams kyi (=kyis) mdzad pa/ deng sang gi bar gong nas gong du 'phel bar gyur pa'o/. 
rgyab is sometimes referred to as Bya sa yar rgyab. ${ }^{13}$ Here it is likely that Bya sa denotes the vicinity of the ancient Bya sa temple (Bya sa lha khang) about five kilometres from rTse thang (Ch. Zédāng) in present-day sNe gdong County (Ch. Năidōng xiàn). In the past this imperial temple was close to the Phag mo gru pa power base at sNe gdong. We may assume that the area around Bya sa marked the most eastern part of Yar rgyab, bordering the territory of the Phag gru rulers further east. ${ }^{14}$ If one follows Byang chub rnam rgyal's sketch, the furthest geographic expansion of the Yar rgyab realm measured an area of some 130 kilometres in length from west to east on the southern banks of the gTsang po river (i.e. gTsang po lho rgyud). It lay at the centre of Central Tibet and comprised the neighbouring principalities of both Gong dkar and Yar rgyab (see fig. 2).

Earlier in the same passage on Byams pa gling pa's genealogical origin, Byang chub rnam rgyal stresses that the master's forefathers were closely associated with the sNe gdong rulers from the founding of the Phag mo gru pa dynasty under Ta'i si tu Byang chub rgyal mtshan. The early, or first, officials in charge of what was Yar rgyab at that time were the brothers (sku mched rnams) who governed the southern gTsang po ranges from Bya sa to the Jo mo kha rag mountain massif, among them Byams pa gling pa's father Drung chen Tshul khrims rgyal mtshan. Byang chub rnam rgyal portrays him and his three brothers as high officials of Central Tibet and the sons of the powerful nobleman rDo rje bkra shis du dben sha (fl. $14^{\text {th }}$ cent.), also known as rDor bkras du dben sha. ${ }^{15} \mathrm{He}$, in turn, was the son of dPon rTa mgrin rgyal

13 rNam rgyal mgon po, Gongkarwa Biography II: 3a2; Ehrhard 2002b: 131, 349.

14 For the tenth month of 1484 (wood-dragon year), the Fourth Zhwa dmar pa reports the bestowal of ordinations and the consecration of newly built receptacles in the realm of his patron(s) from Yar rgyab, a region that is said here to have stretched from Bya sa temple to Grwa and Dol; cf. Chos grags ye shes, Fourth Shamar Autobiography, p. 964: zla ba bcu pa'i tshes drug la bteg stel/bya sa'i gtsug lag khang nas gra dol gyi//dge ba'i gnas su sbyin pa'i bdag po yis//gsar du bzhengs pa'i rten la rab gnas dang //rab byung dge tshul don du gnyer rnams bsgrubs/.

15 Byang chub rnam rgyal provides a synopsis of rDo rje bkra shis du dben sha's secular accomplishments and the territory that he oversaw; see Byang chub rnam rgyal, Jampalingpa Biography, f. 4a1-7: de'i sras rdo rje bkra shis du dben sha ni/ sa skyar ti shri (=shrì) kun dga' blo gros kyi zhabs la btugs (=gtugs) nas/ ri klung mdo khra dang / gan pa rting khebs/ dam phug sdzong (=rdzong) sogs 'bri 'tshams (=mtshams) gangs dkar po tshun gyi zhal bdag dang / nyang smad dga' ba gdong dang / bya rog tshang gi stong dpon/ chu sgo gzhung gsum gyi khrims bcod (=gcod) sogs mdzad/ hor rgyal po gong ma tho gan thi mur gyi lung bzang po phebs nas/stod o thon chol kha bsrung ba'i du dben sha gsum gyi che shos/gon min gi du dben sha'i las kha lon/ shel tham gling drug thu shu bel kha (=tho shu sbel kha)/ stag mgo nor bu gsum pa/ gser sgor/ dngul gyi byang ma/ shag shag khrims rnga/ rnga thug sgo mdung / shel dang lcags kyi tho sta sogs/dpon chen dang lung las kha mnyam pa thob/de rjes ta'i si tu chen po byang chub rgyal mtshan pa / shangs pa dpon chen rgyal ba bzang po'i phyir du btsang (=gtsang) phyogs la phebs dus/yul phyogs dang bstun pa'i dpon g.yog du sbrel/ phag mo grub (= gru) pa'i bstan pa tshol dus kyi dang ru g.yas pa mdzad nas/rong rigs gsum 'og tu bcug gzhis kha rin dpungs (=spungs) kyi 'gram bting / nyang stod stag rtse brtsigs pa sogs 'jig brten (=rten) gyi che ba'i lo brgyus (=rgyus) bgrang gis mi ldang ba yod/. According to this sketch, 
mtshan, who was a high-ranking Tshal pa official during the Sa skya-Yuan administration (ca. 1250-1354). ${ }^{16}$ Apparently, rDor bkras du dben sha became an important ally of Byang chub rgyal mtshan in gTsang, where the first Phag gru ruler installed him as his commander-in-chief ( $d u$ dben sha; Ch. duyuanshuai) at Bya rog tshang. ${ }^{17}$ rDo rje bkra shis du dben sha's four sons, listed from the oldest to the youngest, were the officials (1) Drung rDo rje rgyal po (fl. second half of the $14^{\text {th }}$ cent.), (2) Drung chen Tshul khrims rgyal mtshan (fl. late $14^{\text {th }}$ cent.), (3) Drung chen Kun dga' dpal bzang, and (4) Drung chen bZhi 'dzom (1372/73-1446). The last, also known by the name I nag bZhi 'dzom, was the uncle of Byams pa gling pa and the grandfather of Gong dkar ba. Byang chub rnam rgyal elaborates that the four brothers were given leading offices not only in gTsang, where their father was ruling, but also in the administration of southern dBus, including the posts of the Gong dkar District Officer and the Yar rgyab Great Officer. The fifth Phag gru ruler, Gong ma Grags pa rgyal mtshan (1374-1432), appointed rDor bkras du dben sha's second son, Drung chen Tshul khrims rgyal mtshan, the chief official of g. Yon ru district (g.yon ru'i las chen) in gTsang and the Great Officer of Yar rgyab (yar rgyab kyi dpon chen) in the

rDo rje bkra shis served different offices in charge of a huge region in gTsang during the Sa skya-Yuan period. It comprised parts of Lower Nyang (Nyang smad) and the area south and southwest of Sa skya. This territory extended up to the Gangs dkar po mountain massif of 'Bri mtshams (var. 'Dri mtshams; 'Bring mtshams), including Ri klung mdo khra, Gan pa (= Gam pa rdzong ?), rTing khebs (= gTing skyes ?) and Dam phug Fortress. Byang chub rnam rgyal further relates that rDo rje bkra shis obtained the imperial command for the office of the Gon min gi du dben sha from the Yuan emperor Toyan Temür (Gong ma Tho gan thi mur, r. 13321368); this rank, he stresses, was equal to that of a dpon chen (dpon chen dang lung las kha mnyam pa). Later, during the rise of the Phag mo gru pa, rDo rje bkra shis exerted control over central parts of gTsang, including Rong rigs gsum as well as gZhis kha Rin dpungs and sTag rtse in Upper Myang (Nyang stod). I am indebted to Karl-Heinz Evering for helping me with the special Yuan terminology in this section. The toponym 'Bri mtshams Gangs dkar po can be identified as the border region of the rGyal [mkhar] rtse rulers in the south; see Everding in this volume and Everding 2013: 244. See also Ahmad 1995: 177; Sørensen and Hazod 2007: 383 n. 34. For Bya [rog] tshang and dGa' [ba] gdong (var. sGa gdong) where rDo rje bkra shis held the office of chiliarch (stong dpon; Ch. qianfuzhang), see Sørensen and Hazod 2007: map 9, $187 \mathrm{n}$. 450, 98 n. 102; Hazod 2009: 211, map 6.2. Modern accounts of the Thon mi family line report that the Yar rgyab pa obtained the post of dpon chen during the Sa skya hegemony of Tibet; see g.Yu gra bsod tshe: 12. See also dGe slong Blo bzang don ldan, p. 6: phyis sa skya pa 'i skabs sde dpon thon pa'i sku ngo zhig nas bod kyi rgyal po lo bzhir mdzad pa'i lo rgyus dang / [...].

16 See note 20 below.

17 See Byang chub rgyal mtshan, Po ti bse ru: 246 (here rDo bkras du dben shwa); Czaja 2013: 149 n. 136. See also Byang chub rnam rgyal, Jampalingpa Biography: 4a2-3 (as in note 15). Byams pa gling pa describes rDor bkras du dben sha's allegiance to the Phag mo gru pa in his own poetic wording; cf. bSod nams rnam rgyal, rGyal chen gling gi 'bum chen dkar chag, $\mathrm{f}$. 2a7-8: rdo rje bkra shis zhes grags pa// byang phyogs sa yi dbang phyug gis// skal ba bzang po nyid byin pa'il/ bkra shis rtags kyi ba dan gyis// dpal ldan phag mo'i gru bo che 'il/ mdzes pa sngon med bskyed pa lall. 


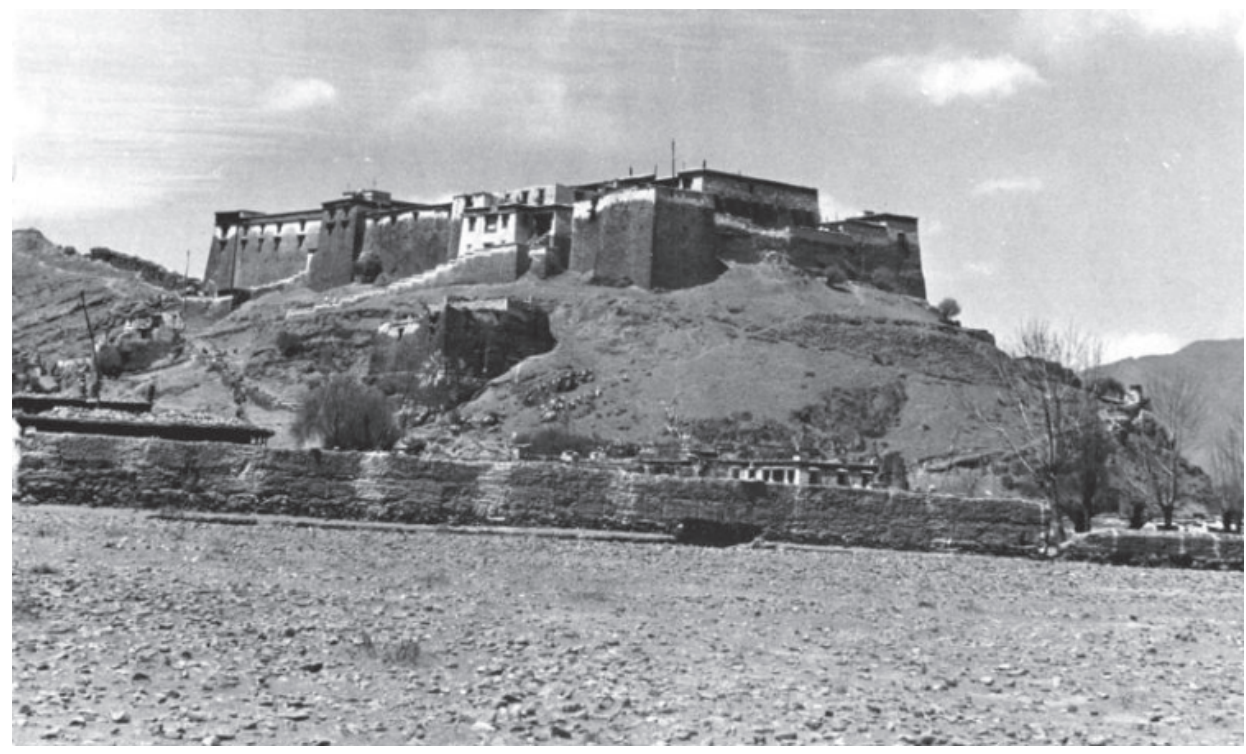

Fig. 3: Gong dkar Fortress at Lower sKyid shod (Photo: Ernst Schäfer, April 1939; German Federal Archive, Bild 135-S-15-24-12). The original caption mistakenly reads "Tschitischio" (1Ce bde zhol).

dBus Province. ${ }^{18}$ Was he, the early-deceased father of Byams pa gling pa, the first official under the Phag mo gru pa to become the ruler of what constituted Yar rgyab in the late fourteenth or early fifteenth century? In any case, it seems that the Yar rgyab pa became firmly established in southern dBus during the reign of Gong ma Grags pa rgyal mtshan (r. 1385-1432). Byang chub rnam rgyal depicts a close relation with the Phag mo gru pa government during the rule of the fifth gong $m a$, who entrusted three of rDor bkras du dben sha's sons with high administrative positions and land estates to the west of sNe gdong, comprising the valleys of Grwa, Dol, gZhung and Gong dkar. ${ }^{19}$ These fertile valleys on the southern gTsang po side, which

18 Byang chub rnam rgyal, Jampalingpa Biography: 4b2-3. The whole passage on the four sons recounts that Tshul khrims rgyal mtshan's younger brother, Drung chen Kun dga' dpal bzang, became the leader of Chu mig (chu mig gi chen po) under the same Phag mo gru pa ruler, whereas his older brother, Drung rDo rje rgyal po, was appointed as the stong shri mgon legal officer of Central Tibet (dbus rtsang gi khrims pa stong shri mgon gyi las kha) by the first Ming emperor Taizu (Gong ma ta'i ming Tha'i dzu, r. 1368-1398) and as the g.Yas ru military commander ( g.yas ru'i dmags [=dmag] dpon) by the second Phag gru hierarch, 'Jam dbyangs gu shri chen po (r. 1364/65-1373); cf. ibid.: 4a1-5a3. The accomplishments of the four Yar rgyab brothers are also recounted by Byams pa gling pa himself; cf. bSod nams rnam rgyal, rGyal chen gling gi 'bum chen dkar chag: 2a8-b5.

19 The close ties with the Phag mo gru leadership did not last long after the death of Gong ma Grags pa rgyal mtshan (d. 1432). In 1434 (wood-tiger year) Yar rgyab became directly involved 
covered central parts of the old g.Yo ru district and had previously been under Tshal pa rule, became the family's main territory. ${ }^{20}$

\section{Gong dkar}

In this context, the estate at Gong dkar (gZhis kha Gong dkar), with its prominent fortress (see fig. 3) near the confluence of the gTsang po and the sKyid chu rivers, played a crucial role for the governance of the wider region towards the east. Ta'i si tu Byang chub rgyal mtshan stressed Gong dkar's strategic importance in his Testament, describing the pair of sNe gdong and Gong dkar as a unit of estates comparable to a human body's central organs of the lungs and the heart. ${ }^{21}$ The first

in the internal disputes concerning the succession to the sNe gdong throne. The Yar rgyab rulers sided with the opposing fraction of the sNe gdong court under the gong $m a$ 's younger brother Che sa Sangs rgyas rgyal mtshan (1389-1457). As the Che sa's attempt to seize power of the throne from his own son Grags pa 'byung gnas (1414-1448) failed, the Yar rgyab pa provided him shelter for the period he was banned into exile (until the year 1457). The circumstances of these events are briefly sketched in various historical chronicles, e.g. bSod nams grags pa, New Red Annals: 218f.; Ahmad 1995: 151f.; see also a synopsis of the events in Czaja 2013: 19f., 218-224. The sources report that Yar rgyab was a major battlefield during this internal conflict surrounding Grags pa rgyal mtshan's succession; cf. ibid., 221 n. 43, and Byang chub rnam rgyal, Jampalingpa Biography: 21b5-6. The exact role of the Yar rgyab family house in this conflict is unclear, but their direct military involvement reflects the influence they had gained on the central court, directly challenging the new ruler Grags pa 'byung gnas. See also g.Yu gra bsod tshe 2016: 13f. Under the succeeding Rlangs rulers, Yar rgyab (and Gong dkar) again turned against the sNe gdong court; cf. bSod nams grags pa, New Red Annals: 222, 224f.; Ahmad 1995: 152f.; Czaja 2013: 227, 230f., 235f.

20 During the period of the Sa skya-Mongol administration, the three valleys formed individual estates ( $m i$ sde) under the Tshal pa myriarchy (Tshal pa khri skor), see Sørensen and Hazod 2007: map 1 (nos. 26-28); appendix vi.1, "The Gung thang dkar chag": $31 \mathrm{~b} 1$ (here Gra dol gzhung gsum). rDor bkras du dben sha's father, dPon rTa 'grin (=mgrin) rgyal mtshan, and his grandfather, dPon rGyal po dga', were both officials at the Tshal pa court; cf. Byang chub rnam rgyal, Jampalingpa Biography: 3b7-4a1. Sørensen and Hazod identify Grwa, Dol and gZhung as having constituted essential areas under the control of the Yar rgyab ruling house during most of the late $14^{\text {th }}$ century and the $15^{\text {th }}$ century, and probably even for a longer period. For historic information on the Grwa, Dol and gZhung valleys, see Sørensen and Hazod 2007: 171-175 n. 423.

21 Po ti bse ru, pp. 351f.: sne gdong gong dkar gnyis po 'di/ sde 'di'i glo snying zung 'brel yin/ 'di gnyis kyi gnyer pa gnyis kyang / pha mes nas mi rabs mi rabs su/gdan sa 'di'i bya 'dab 'og them pa rtsar skyes pa'i mi ma gtogs/skya log sngo log dang / sde mi gcig pa'i mi/ mi'i hor 'dra byas pa'i rigs pho mgo mtho zhing / bya ba pher yang / 'di gnyis kyi gnyer mi 'os/ chung chung nas/ gsol ja gzim g.yog byas shing / dpon des [352] brdungs btags/ btang bzung ci byas kyang / yi chad 'khang ra mi byed/ sdug theg pa'i mi/ bsam rgyu sde 'di las med pa'i mi la bsko dgos/. See also Czaja 2013: 469. The strategic importance of Gong dkar Fortress during the sixteenth century is also emphasised in the annals of the Fifth Dalai Lama; see Ahmad 1995, p. 158: "This (fortress of) Gon-dKar is like a central connecting point between dBus and gTSan. If it is not held by our men, there will be misfortune for Tibet. Therefore, the fortress must not be surrendered." 
Phag mo gru pa ruler frequently resided at Gong dkar Fortress (Gong dkar rdzong), which he is said to have built along with other fortresses for the country's administration. ${ }^{22}$ The fortified castle on the southern gTsang po shore at the southernmost point of Lower sKyid shod (sKyid shod smad) is thus frequently called the "king's second palace" (rgyal po'i pho brang gnyis pa). ${ }^{23}$ Byang chub rgyal mtshan's fifth successor on the sNe gdong throne entrusted this important estate to his official Drung chen bZhi 'dzom, the youngest of rDo rje bkra shis du dben sha's sons. Drung chen bZhi 'dzom can be considered one of the most powerful men in Central Tibet at that time. ${ }^{24}$ Before he was appointed the district officer ( $r d z$ ong dpon) at Gong dkar by the gong ma Grags pa rgyal mtshan, Drung chen bZhi 'dzom was the chief official (mi dpon) of the Grwa region, about fifty kilometres downstream (i.e. east) from Gong dkar palace. In charge of the large valley complex consisting of Grwa nang and Grwa phyi, he resided (and possibly passed away) at rGyal chen

22 bSod nams grags pa, New Red Annals: 210. See also Czaja 2013: 468f.; Sørensen and Hazod 2007: 208f. n. 542.

23 See, inter alia, Byang chub rnam rgyal, Jampalingpa Biography: 4 b6 (as in note 24); rNam rgyal mgon po, Gongkarwa Biography II: 3a3; Jackson 1989: 5; bSod nams rnam rgyal, rGyal chen gling gi 'bum chen dkar chag: 2b4 (here: gong dkar rgyal po'i pho brang).

24 Cf. Jackson 1983: 11. This is likewise reflected in the portrayal by Byang chub rnam rgyal; cf. Jampalingpa Biography: 4b5-5a3: sras bzhi pa drung chen bzhi 'dzom pas/ gdan sa thel du spyan snga grags pa byang chub pa dang / sne'u gdong du gong ma grags pa rgyal mtshan pa' $i$ zhabs la btugs (=gtugs)/gong ma de nyid kyi thugs kyi sras dam par gyur pa la brten nas/ thog mar gra lung pa'i mi dpon dang / de rjes su rgyal po'i pho brang gnyis pa gong dkar dpal gyi sde (=bde) chen brgyud pa dang bcas pa la 'jags pa'i sko 'ja' gnang / rgya'i rgyal po gnyis pa gong ma a wam gyi lung gi (=gis) du shri'i las kha gnang stel du shri dzung phing gon bzhi 'dzom bod che chung dbus rtsang gi sa char gong ma'i tshab tu [5a] shes su bcug pa yin zer ba'i 'ja' sa/ lung las kha tham kha dang bcas pa lon/ gong ma chen mo grags pa rgyal mtshan pa' $i$ phrin las thams cad la mnga' brnyes par gyur pas/ 'jig brten (=rten) gyi che ba'i yon btan (=tan) bsam gyi (=gyis) mi khyab par grags pa ste/ [...]. For bZhi 'dzom, see also bSod nams rnam rgyal, rGyal chen gling gi 'bum chen dkar chag: 2b1-5. As a patron bZhi 'dzom was involved in the printing of the works of Tsong kha pa (1357-1419), following the orders of the fifth Phag mo gru pa ruler; cf. bSod nams grags pa, New Red Annals: 237; see also Jackson 1983: 12 and Jackson 1989: 2-5. He and his elder brother, Drung chen Tshul khrims rgyal mtshan, were apparently married to the same Yar rgyab queen Bu 'dren dpal (d. ca. 1430). Bu 'dren dpal, who gave birth to the Yar rgyab nobles lHun grub bkra shis, *bSod nams rgya mtsho / *Byams pa rgya mtsho (name uncertain), rGyal ba shes rab and lHa dbang dpal 'byor (cf. bSod nams rnam rgyal, rGyal chen gling gi 'bum chen dkar chag: 2b5-3a6), may in fact have been married to all four sons of rDo rje bkra shis du dben sha. Her eldest son, dGe bsnyen 1 Hun grub bkra shis, was the officer of Yar rgyab, whereas rGyal ba shes rab (d. ca. 1430s/40s) and 1Ha dbang dpal 'byor became district officers of Gong dkar. Nang so rGyal ba shes rab was the son of bZhi 'dzom and the father of Gong dkar ba; cf. Byang chub dbang rgyal, Gongkarwa Biography I: 16. He is referred to as Gong dkar District Officer by Grags pa rdo rje; cf. mKhan rgyud rnam gsum byon tshul gyi rnam thar: 21a5. 1Ha dbang dpal 'byor was active in the 1430s; cf. note 43 below. 
gling, a major Yar rgyab estate in the central plains of Grwa nang..$^{25}$ It seems to have been at about this time that Grwa became the headquarters and religious centre of Yar rgyab, with large estate holdings and the family's main monasteries. ${ }^{26}$ It was here that dGe bsnyen 1 Hun grub bkra shis (fl. early $15^{\text {th }}$ cent.), the son of Drung chen Tshul khrims rgyal mtshan and the older brother of Byams pa gling pa, re-established a monastic community at the old temple of Grwa thang (var. Gra thang), in the lower part of the Grwa nang valley (Grwa nang mda'), and founded Byams pa gling monastery, which came to fame as the monastic centre of the Yar rgyab pa under the direction of his younger brother. ${ }^{27} \mathrm{dGe}$ bsnyen $1 \mathrm{Hun}$ grub bkra shis followed on the throne as the Yar rgyab ruler, apparently after his father's death in the first years of the fifteenth century. ${ }^{28}$ The new Yar rgyab officer was probably also based at the family court in rGyal chen gling or elsewhere in Grwa. He obtained approval for holding this office from the same sNe gdong ruler who had entrusted his father with the governance of Yar rgyab and his uncle, Drung chen bZhi 'dzom, with the rule of Gong dkar. As we are informed by Byang chub rnam rgyal, from the time of Drung chen bZhi 'dzom's rule as the Gong dkar district's officer, the candidate for this powerful office was chosen from among the Yar rgyab family. ${ }^{29}$

\section{sKul and 'Ching ru}

The territory under the Gong dkar District Officer formed the western part of the greater family realm. This included the immediate area to the south of Gong dkar Fortress, as well as the valleys to its east and west.

The area below the hill upon which Gong dkar Fort lies and where the rulers in charge of Gong dkar resided consists of two separate valleys. These are frequently mentioned as a pair under the toponym sKul 'Ching ru. ${ }^{30}$ The short and less populated valley to the south is still called "Kül" (sKul; var. bsKul) by locals. ${ }^{31}$ The valley to

25 Byang chub rnam rgyal; Jampalingpa Biography: 31b7-32a1.

26 See also Sørensen and Hazod 2007: 172 n. 423, where it is concluded that "from the $14^{\text {th }}$ cent. the area of Grwa was under the Yar-rgyab ruling house." g.Yu gra bsod tshe concludes that Grwa nang was the centre of Yar rgyab; cf. sDe pa yar rgyab pa'i skor gyi dpyad gleng: $15 \mathrm{f}$. (as in note 58 below).

27 Byang chub rnam rgyal, Jampalingpa Biography: 5a6-7. See also Jackson in this volume.

28 The early death of Drung chen Tshul khrims rgyal mtshan is mentioned by Byang chub rnam rgyal; cf. Jampalingpa Biography: $6 \mathrm{a} 5$.

29 Byang chub rnam rgyal, Jampalingpa Biography: 4b6-7 (as in note 24). See also g.Yu gra bsod tshe 2016: 18.

30 See Sørensen and Hazod 2007: 168f. n. 421. The two valleys to the south of Gong dkar Fortress constituted an estate unit ( $m i$ sde) under the Tshal pa rulers during the Sa skya-Yuan administration; cf. ibid.: map 1, nos. 21/22 (with tentative location); see also appendix vi.1, "The Gung thang dkar chag": $31 \mathrm{~b} 1$ (here sKul ching ru). That 'Ching ru belonged to the Tshal pa myriarchy is also mentioned in the colophon of an early Gong dkar print; cf. Fermer 2010: 266f.

31 Interviews, Gong dkar (Tibet) and Dehradun (India), 2015. 
the southeast facing the ruins of the fortress can now be identified as the 'Ching ru (var. mChing ru; 'Phying ru) mentioned by various sources. The lower part of this valley is where Gong dkar ba built his monastic seat Gong dkar chos sde (or Gong dkar rdo rje gdan) in the years 1464-1476. ${ }^{32}$ Today the valley is just called "Gongkar", and its upper end, which leads over the sKya rog pass to Yar 'brog, is respectively called "Gongkar-phu" (Gong dkar phu) ${ }^{33}$ Having identified the original name of the valley, 'Ching ru, we now know that it was a site of early printing activity. ${ }^{34}$ More precisely, the locality or estate of gNam mdun (var. gNam 'dun) in 'Ching ru seems to have constituted an early printing house or a workshop for manufacturing printed books under the commission and approval of the ruling court at Gong dkar. ${ }^{35}$

\section{gZhung}

To the east, the territory under Gong dkar extended as far as gZhung, the valley lying to the west of Dol. ${ }^{36}$ Known as the valley where the rNgog pa bKa' brgyud branch safeguarded its lineage at the convents of sPre zhing (var. sPrel zhing, sPre'u zhing) and Ri bo khyung lding, ${ }^{37}$ gZhung accommodated two estates under the command of the Gong dkar District Officer.

Byams pa gling pa's biography mentions rNam rgyal rab brtan as the place in gZhung to which Gong dkar ba invited his teacher in 1463 (water-sheep year) to receive his novice ordination (dge tshul; śrammanera).$^{38} \mathrm{rNam}$ rgyal rab brtan is specified more precisely in the biography of Gong dkar ba, where it is described as the private estate (sger gzhis) of his chief attendant (nye gnas chen mo), who was

32 Byang chub dbang rgyal, Gongkarwa Biography I: 107-113.

33 Interviews, Gong dkar (Tibet) and Dehradun (India), 2015.

34 The blocks of three old Gong dkar prints can be identified as having been manufactured in 'Ching ru; cf. Jackson 1989: 12 (here 'Ching ru dge 'phel dgon gsar); Fermer 2010: 266f. (here Yul bzangs 'ching ru); dPal brtsegs bod yig dpe rnying zhib 'jug khang (ed.) 2013, Brief Introduction to the History of Tibetan Printing Technology: 14 (here mChing ru dpal gyi gnam 'dun).

35 At gNam 'dun of mChing ru, the blocks of an early print of Śāntideva's Bodhicaryāvatāra were prepared in the water-tiger year of 1422; cf. ibid.: 14 (as above). Byams pa gling pa, during his sojourn at the Gong dkar estate in 1434 (wood-tiger year), compiled a register of the existing books (or printing blocks?) of gNam mdun (gNam mdun pa'i glegs bam gyi dkar chag); cf. Byang chub rnam rgyal, Jampalingpa Biography: 22a3.

36 During the imperial period, the valleys of Dol and gZhung formed an administrative unit (i.e. stong sde); cf. Hazod 2009: 209; Sørensen and Hazod 2007: 171 n. 423.

37 For the rNgog pa sect in gZhung, cf. ibid. 175 n. 423, and Ngag dbang thub bstan 2014: 172177.

38 See Byang chub rnam rgyal, Jampalingpa Biography: 46b2-4 (here gZhung gi rnam rgyal rab brtan). Strangely, Gong dkar ba's biography dates his novice ordination to the year 1458 (earthtiger); see Byang chub dbang rgyal, Gongkarwa Biography I: 29. rNam rgyal rab brtan is again mentioned by Byang chub rnam rgyal as the site where Gong dkar ba received instruction from his master in the year 1474 (wood-horse); cf. Jampalingpa Biography: 68b5-6. 
named brGya byin. ${ }^{39}$ The original site of rNam rgyal rab brtan is most probably today's rNam rab village in the middle of the valley. Today it is the valley's largest settlement. Its name seems to derive from this estate dating to the fifteenth century.

Byang chub rnam rgyal, a folio earlier in the same text, also refers to another estate in the gZhung valley. For the year 1460 (iron-dragon), he reports that Gong dkar ba invited Byams pa gling pa to dGa' ldan lha rtse in gZhung to receive his monastic ordination ( $r a b$ tu byung $b a) .{ }^{40}$ Gong dkar ba, under his birth name Grwa lnga rgyal po, was ruling Gong dkar at the time and gZhung obviously formed a part of his territory to the east. Three decades later, in 1492 (water-mouse year), parts of the Gong dkar district, including most probably dGa' ldan lha rtse, fell into the hands of the invading Rin spungs troops. ${ }^{41}$ The original site of dGa' ldan lha rtse estate is not known to today's inhabitants of the gZhung valley. ${ }^{42}$

\section{lCags zam}

To the west, the Gong dkar territory seems to have included the area of lCags zam $\mathrm{Chu}$ bo ri. The region around the sacred Mount Chu bo ri owes its name to the fifteenth-century saint Thang stong rgyal po (1361?-1485), who built his monastic seat, 1Cags zam bla brang, on the northern slope of the mountain, as well as an ironchain bridge (lcags zam) connecting the southern and northern shores of the gTsang po. ${ }^{43}$ On the western mountain slope is the seat of Gong dkar ba's root lama, Brag thog pa bSod nams bzang po (fl. first half of the $15^{\text {th }}$ cent.). Brag thog chos rje, as he

39 Byang chub dbang rgyal, Gongkarwa Biography I: 97, 173f. A wall inscription at rNam rab Dwags po grwa tshang mentions a certain mNga' bdag Shag pa le nag brgya byin, who supported the Sa skya master Dwags po bKra shis rnam rgyal (1398-1458) in founding this monastery at rNam rab; cf. Ngag dbang thub bstan 2014: 149.

40 Byang chub rnam rgyal, Jampalingpa Biography: 45a2-4.

41 Cf. Chos grags ye shes, Fourth Shamar Autobiography, p. 972: byang phyogs bgrod la mngon du phyogs na yang //mthu stobs chen po'i dpung gi gzi brjid kyi (=kyis)//yar rgyab sbyin bdag 'khor bcas dpa' bskongs nas//re zhig 'gro ba'i go skabs rnyed ma gyur//dol phu bkra shis rnam rgyal 'dug pa'i tshe/ /'khor los bsgyur rgyal gser mdog rtogs brjod bris//gzhung gi dga' ldan lha rtse zhes bya bar//mi dbang don yod rdo rje rgyal po la//snyan bskul bgyis ltar 'jigs med byin pa yis/ /yul 'khor de rnams bde dang ldan par byung /. The wider context of the military campaign against dBus led by the Rin spungs ruler Don yod rdo rje (1463-1512) is addressed by bSod nams grags pa; cf. New Red Annals: 227. See also Czaja 2013: 243; dPa' bo gtsug lag 'phreng ba, Feast for the Learned Ones: 579.

42 However, a site called dGa' ldan gyang (lit. "ruins/walls of dGa' ldan;" Ch. Gāndān jiāng) is said to be found in a small side valley about 3 kilometres southwest of present-day rNam rab village; communication with a rNam rab native, Vienna, February 2016.

43 In fact, the Yar rgyab lords are found among the supporters of Thang stong rgyal po, who held a ritual feast on their behalf in Grwa; cf. Stearns 2007: 209f. The Yar rgyab pa's influence on Chu bo ri is somehow reflected by the fact that the people of Gong dkar, under the leadership of $1 \mathrm{Ha}$ dbang dpal 'byor, deliberately used loads of iron that Thang stong rgyal po had shipped back from Bhutan in the 1430s to build the iron bridge at Chu bo ri; see ibid.: 292, 301, 552 n. 817. 
is also called, instructed Gong dkar ba in the doctrines of the Sa skya pa in around the 1440 s or 1450s, and must have been a leading lama at the court of Gong dkar ba as a young ruler, or at that of his father, rGyal ba shes rab, or his grandfather, Drung chen bZhi 'dzom, who had previously governed the district. ${ }^{44}$ Byang chub rnam rgyal mentions that Brag thog monastery as well as three other monasteries under the Gong dkar administration (gong dkar mnga' zhabs kyi sde dgon) participated in commemorative services on behalf of the deceased Phag gru ruler Grags pa rgyal mtshan in the year 1434 (wood-tiger). The other three monasteries are the rNgog pa seat of sPrel zhing in gZhung, Rin chen dge stengs in the sKul valley, and the unlocated community of 1 Hun po sgang. ${ }^{45}$ These four monasteries can thus be considered as having been major religious institutions affiliated with the Gong dkar local government at that time (see fig. 4).

\section{Byang thang}

At a later point in time, the valleys to the west of lCags zam were also affiliated with Gong dkar and its largest monastery, Gong dkar Chos sde. The above-mentioned Brag thog monastery lies on the western side of Mount Chu bo ri, with the opening of the Byang thang valley to the southwest. Brag thog was, and still is, the main monastery for the village community in the lower Byang thang valley. In the upper part of the valley, Gong dkar chos sde monastery ran an estate with a protector chapel until the 1950s. Prior to the Chinese occupation, the monastery's estate retained fields of the size of $100 m u^{46}$ and was known by the name dGra 'dul gzhis kha (Ch. Zhàndū xīgá).$^{47}$ Still further upstream, in Kha rag (var. mKha' reg; Ch. Kărè) of

44 Nang so lHa dbang kun dga' (fl. second half of the $15^{\text {th }}$ cent.) succeeded Gong dkar ba as the district officer at Gong dkar and became one of his major patrons. On this individual, see New Red Annals: 225; Byang chub dbang rgyal, Gongkarwa Biography I: 172; rNam rgyal mgon po, Gongkarwa Biography II: 5b3-5.

45 Byang chub rnam rgyal, Jampalingpa Biography, ff. 21b6-22a1: de nas gzhis kha gong dkar la thegs nas/ zla ba bzhi pa'i nang du/ gong ma chen po grags pa rgyal mtshan pa'i lo dus kyi sgrub mchod chen mo zhig gong dkar mnga' zhabs kyi sde dgon/sprel zhing dang / rin chen dge stengs/ brag thog / lhun po sgang sogs nas sngags pa mang po [22a] bsags nas mdzad kyi 'dug pa'i dus su/ [...]. According to a Gong dkar native, the former site of Rin chen dge stengs can be located on the western mountain slopes of the lower sKul valley. Today the place is called "Gethang" and still bears ruins of old buildings and the remains of a stüpa complex; communication, WeChat Voice Messenger, October 2016. The location of 1Hun po sgang monastery remains unidentified, although it may have been where the printing blocks of bSod nams rtse mo's Samputatantra commentary (i.e. Sam bu ța'i ți ka gnad kyi gsal byed) and two grammatical works by Zhwa lu lo tsā ba were prepared; see Jackson 1983: 9, 18 (here Chos kyi sde chen 1Hun po sgang); Pho brang po ta la dpe rnying bsdu sgrig khang (ed.) 2015: 318, no. 01987(6), 319 no. 01988(6).

46 Chinese area unit; $1 m \check{m}=666.7 \mathrm{~m}^{2}$.

47 Interview, Byang thang, Tibet, 2010. See also Jackson 2015: 246 no. 22. 
present-day sNa dkar rtse County (Ch. Làngkăzi xiàn), the monks from Gong dkar maintained a protector chapel within an estate at the foot of Mount Jo mo kha rag. ${ }^{48}$ How far the territory under the Gong dkar rulers expanded in the fifteenth century, and if it included the region to the west of lCags zam up to Mount Kha rag as Byang chub rnam rgyal claims, is a question that cannot be answered here.

\section{Chu shul}

The Gong dkar rulers were also present in the region around the confluence of the sKyid chu and the gTsang po rivers, an area that is crossed by travellers heading either north to Lhasa or east towards sNe gdong via Gong dkar and Yar rgyab. In addition to their influence on lCags zam on the southern gTsang po bank, there is reason to assume that the Gong dkar officers gained control also over parts on the gTsang po's northern bank. The old Samvara temple of Srin po ri (established in the early $13^{\text {th }}$ cent.) on the northern shore, opposite Gong dkar Fortress, became an affiliate (dgon lag) of Gong dkar chos sde monastery at some unknown point in time. ${ }^{49}$ On the back of the mountain behind Srin po ri, at the confluence of the sKyid chu and gTsang po rivers, a mountain cave (brag phug) of Gong dkar ba can still be found. ${ }^{50}$ Also earlier, during Drung chen bZhi 'dzom's rule at Gong dkar, the Yar rgyab pa seem to have controlled territory as far as Chu shul (var. Chu shur; Ch. Qūshuî) on the north side of the gTsang po. Drung chen bZhi 'dzom is known for having supported Rong ston Shes bya kun rig (1367-1449), who frequently dwelt in various places in southern dBus before founding 'Phan po Nā lendra to the north of Lhasa. ${ }^{51}$ In line with this, the Fourth Zhwa dmar pa recounts in 'Gos lo tsā ba's lifestory that in 1424 (wood-dragon year), Drung chen bZhi 'dzom invited the Sa skya master with a group of students to Byang chub gling and requested him to set up a monastery. ${ }^{52}$ Byang chub gling, which can possibly be located in a side valley north

48 Interviews, Dharamsala and Dehradun, India, 2010. See also Jackson 2015: 246 no. 24.

49 Interview, Srin po ri, Tibet, 2010. See also Jackson 2015: 246 no. 14.

50 Interview, Gong dkar, Tibet, 2010. See also Jackson 2015: 246 no. 16. Gong dkar ba is said to have used the cave, known by the name sKyid gtsang phug, for contemplative practices related to Vajrakîla (rDo rje phur pa). In fact, his lifestory seems to make reference to this oral narrative; cf. Byang chub dbang rgyal, Gongkarwa Biography I: 94f. Gong dkar ba's biographer locates the site, where his master dispelled a harmful water spirit with the help of a Vajrakila rite within Gong dkar territory.

51 Jackson 1988: ix; Shākya mchog ldan, Rongtön Biography: 322, 331. During Rong ston's lifetime the area around the sKyid chu and gTsang po confluence in Lower sKyid shod was governed by the chiliarch (stong dpon) bSod nams bzang po; cf. ibid.: 322; Jackson 1988: ix.

52 Chos grags ye shes, Gö Lotsawa Biography, p. 49: de'i dbyar dpon bzhi 'dzom pas chos rje rong po dpon slob byang chub gling du spyan drangs/ chos btsugs dgon pa 'debs par zhus te zhabs tog kyang bzang bar mdzad/ der gzims spyil gcig gi rtsig rmang bting bas nged rang gi 'khor rnams 'jigs byung gsung /. 


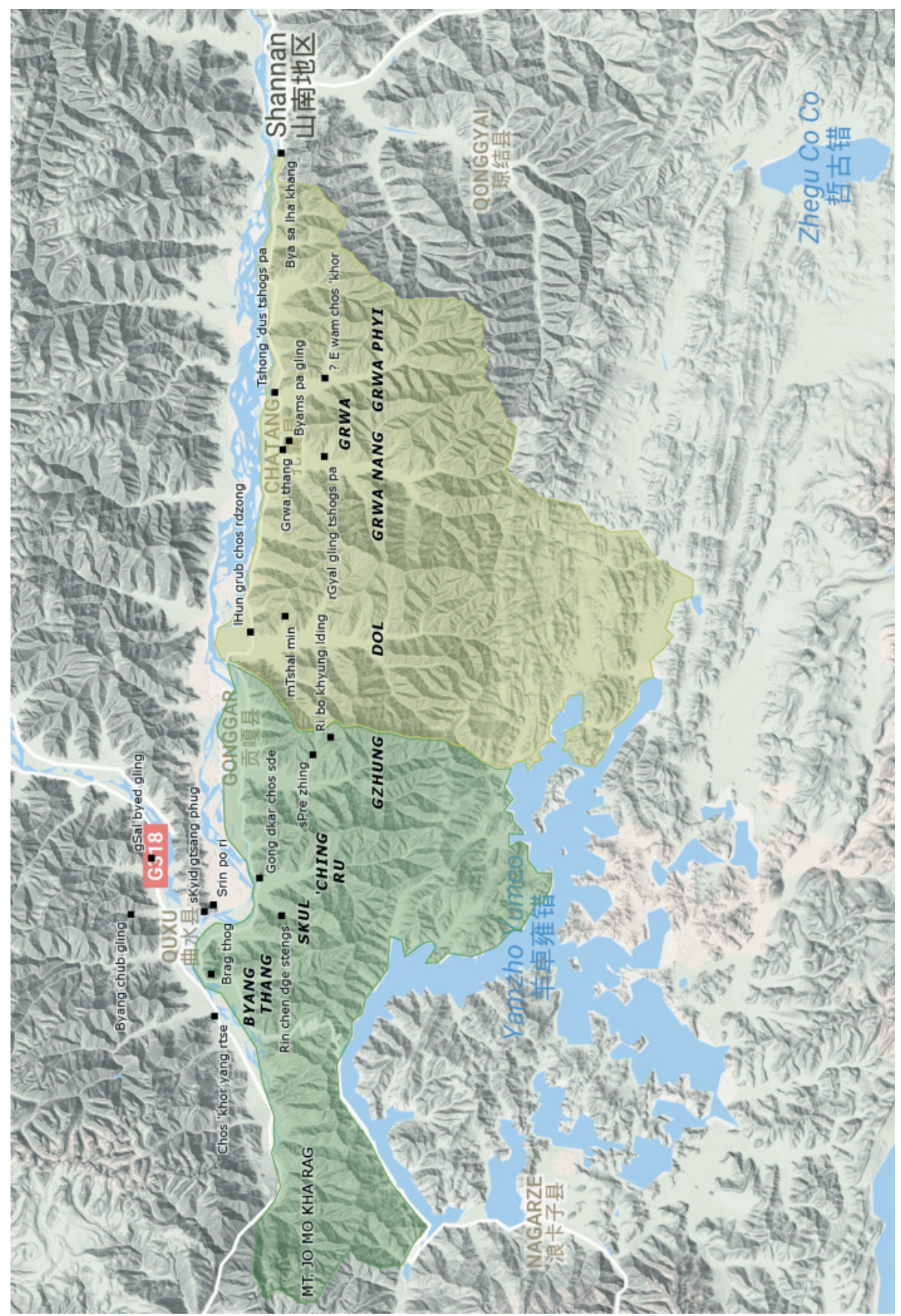

Fig. 4: Monastic Communities under Gong dkar and Yar rgyab (based on Google My Maps; Map data 2016 Google). 
of Chu shul, ${ }^{53}$ became an active site of Rong ston in Lower sKyid shod. It was here that he compiled several of his works and the printing blocks of his Abhisamayālamkāra commentary were prepared. ${ }^{54}$ Also later, at the end of the fifteenth or beginning of the sixteenth century, the Yar rgyab family's influence extended as far north as Chu shul. A certain master with the title Yar rgyab rtogs ldan pa, apparently a Yar rgyab noble, was the resident lama at Chos 'khor yang rtse monastery to the west of presentday Chu shul town. ${ }^{55}$ Also in Chu shul, at present-day Tshar pa snang (var. mTshar pa snang; Ch. Chábā lăng), Gong dkar chos sde monastery maintained a Śrīdevī protector temple with one caretaker until the 1950s. ${ }^{56}$

The region under the Gong dkar District Officer-the western part of the larger Yar rgyab family domain-contained parts of Lower sKyid shod on both sides of the gTsang po, as well as the valleys of Byang thang, sKul, 'Ching ru and gZhung of present-day Gong dkar County (Ch. Gònggá xiàn).

\section{Yar rgyab}

The neighbouring area to the east of Gong dkar was under the control of the Yar rgyab Great Officer. Contemporary biographies refer to this region on the southern gTsang po banks between the gZhung valley and rTse thang of Lower Yar lung as the "domain of Yar rgyab" (Yar rgyab phyogs) or just as Yar rgyab. ${ }^{57}$ From the west to

53 On the possible location of this monastery, cf. Chos 'phel 2004: 136. Rong ston's disciple Shākya mchog ldan mentions Byang chub gling as a seat of his master in Chu shul; see Chos kyi 'khor lo bskor ba'i rnam gzhag, p. 471: mkhan chen padma bzang pos cho shul (=chu shul) byang chub gling dang / chos lung ka bcu pa'i mtshan can gyis gtsang sga gdong gnyis kyang rje rgyal rong pa nyid kyi bzhugs gnas su dmigs nas btab pa'o/.

54 Jackson 1988: xvi, xx. The colophons of Rong ston's commentaries on the Guhyasamāja Tantra and on Kamalaśîla's Third Bhāvanākrama convey that they were compiled at Byang chub gling; see Rong ston gsung 'bum (Khren tu'u: Si khron mi rigs dpe skrun khang, 2008).

55 'Brug pa kun legs (1455-1529) provides this information in a spiritual song he intoned on the occasion of the master's death at Chos 'khor yang rtse; cf. Autobiography Drukpa Künleg: $477 \mathrm{f}$.

56 The defunct temple is known under the name gSal byed gling; interview, Gong dkar, Tibet, 2015. See also Jackson 2015: 245 no. 5.

57 The Fourth Zhwa dmar pa hints at the virtue deriving from the manifold religious activity pursued in the realm of his patrons; cf. Chos grags ye shes, Fourth Shamar Autobiography: 964 (as in note 14 above), 970: yar rgyab phyogs kyi dge ba'i gnas rnams su [...]. Guntram Hazod informed me about the old toponym Yar rgyang (var. Yar rkyang[s], Yar skyang), which stands for a military thousand district (stong sde) of the g.Yo ru (var. g.Yu ru) district and seems to have constituted a larger territory during the imperial period. He tentatively locates the stong sde unit in the southeast of Grwa nang, which to some extent would coincide with the eastern part of the Yar rgyab family domain during the fifteenth century; cf. Hazod 2009: 205, 208; cf. also Czaja 2013: 594, fig. 45 (map by G. Hazod). We thus might ask whether Yar rgyang is the etymological origin for what later became known under the orthography Yar rgyab; email 
the east, it comprised three large valleys that formed the heartland of Yar rgyab: Dol, Grwa nang and Grwa phyi. These valleys, in present-day Gra nang County (Ch. Zhānáng xiàn), constituted the eastern part of the larger family domain. Although governed by members of the same family house, Yar rgyab and Gong dkar remained separate territorial entities and administrative offices. ${ }^{58}$ The officials (nang so) of Yar rgyab administered several estates which frequently appear in the lifestories of those teachers who won the favour of the local rulers. Byams pa gling pa, as a member of the ruling family, naturally received comprehensive backing for his religious training and endeavours throughout his life; he became the main religious head of the Yar rgyab pa. Entrusted with the direction of Byams pa gling monastery and with its land holdings (dbang ris kyi sa cha) in 1436 (fire-dragon year), he took residence at the family monastery in Grwa nang. ${ }^{59}$ In addition to him, three other prominent masters can be identified as the main lamas at the Yar rgyab court during the second half of the fifteenth century. Foremost among them is Lo chen bSod nams rgya mtsho (1424-1482), a Lhokha native and a highly esteemed scholar-saint of the bKa' brgyud lineage who had received his monastic education at rTse thang (var. rTse[s/d] thang) monastery. Lo chen bSod nams rgya mtsho and his teacher Byams pa gling pa acted as the Yar rgyab head lamas during the reign of dPon chen Rin chen bzang po (d. 1475/6) and his wife, rJe btsun chen mo rDo rje bde ma (d. 1491). In the two masters' detailed lifestories, the Yar rgyab officer and his wife, due to their munificent patronage, are respectfully addressed as the "Great Patrons, Father and Mother" (sbyin bdag chen po yab yum pa) or the "Officials, Father and Mother" (nang so yab yum pa). ${ }^{60}$ The court of Rin chen bzang po and rDo rje bde ma sought continuous

correspondence Hazod, 2016-10-15. Sørensen and Hazod understand Yar rgyab literally as "Behind Yar," with Yar standing for the Yar lung valley (i.e. Yar stod mda') to the east; see Sørensen and Hazod 2007: 171 n. 423.

58 bSod nams grags pa summarizes their achievements as patrons in one section, but lists Gong $\mathrm{dkar}$ and Yar rgyab as separate political offices in the sequence of historical events; cf. New Red Annals: 237f.; 217, 222, 224, 225, 227. Byang chub rnam rgyal also describes Yar rgyab and Gong dkar as two separate regions of g.Yor; cf. Jampalingpa Biography: 15a6. Likwise, g.Yu gra bsod tshe 2016 (p. 15) concludes: [...] gong dkar rdzong dang yar rgyab pa'i sde gzhis gnyis gnas gcig tu min par yar rgyab pa'i sde gzhis ni byams pa gling dgon gnas sa'i gra nang du yin pa gsal por rtogs thub. Byang chub rnam rgyal reports on a severe disagreement between the Yar rgyab officials (nang so yar mar) on one side and the Gong dkar fraction (Gong dkar ba) on the other that occurred in the year 1474 (wood-horse). This dispute directly preceded Gong dkar ba's bhikșu ordination; it was settled through the mediation of the Yargyab head lamas, Byams pa gling pa and Lo chen bSod nams rgya mtsho; Jampalingpa Biography: 68a3-7. Lo chen's letters to Gong dkar ba seem to hint at the internal tensions within the family; cf. Ehrhard 2002b: 47-53.

59 Byang chub rnam rgyal, Jampalingpa Biography: 24a2-6.

60 See, for example, ibid.: 37b5, 39b2; Chos grags ye shes, Lochen Biography: 389, 392, 395 (here chos kyi sbyin po yab yum), 416. rDo rje bde ma was celebrated as a great female patroness; $\mathrm{cf}$. Jackson 1983: 12; Ehrhard 2002: 21, 83. 
spiritual guidance from Lo chen, and supported the "Great Translator" in the latter part of his life (ca. 1469-1482). ${ }^{61}$ Based for longer periods in the Dol and Grwa valleys, Lo chen acted as the court lama in charge of the religious affairs of the flourishing realm. In addition to his role as spiritual preceptor, he was entrusted with large-scale renovation and building projects, the production of sacred art, and the compilation and translation of books. ${ }^{62} \mathrm{He}$ acted as the supervisor (do dam pa) for the construction of a large stūpa with many auspicious doors (bkra shis sgo mang mchod rten) at Byams pa gling monastery, where he later succeeded to the abbatial throne. ${ }^{63}$ He introduced his disciple, the Fourth Zhwa dmar incarnate Chos grags ye shes (1453-1524), to the court of his wealthy patrons. ${ }^{64}$ Chos grags ye shes, in his autobiography, describes his patrons from Yar rgyab as important and steady supporters during the second part of his life (ca. 1476-1506). ${ }^{65}$ The Fourth Zhwa dmar pa often visited the family estates and monastic convents in Dol and Grwa, either to seek instructions from his aged teacher or in the role of a royal preceptor, offering his counsel and services to the Yar rgyab queen and her sons. Chos grags ye shes repeatedly presided over the Great Prayer Festival of Byams pa gling (Byams pa gling gi smon lam chen mo), which was hosted annually at the family's main monastery ${ }^{66}$ Both sons of rDo rje bde ma and Rin chen bzang po took ordination from him and became his devoted disciples and supporters. Kun dga' bsod nams rin chen [dbang/ngag gi] rgyal po (d. 1497), also known as Kun dga' rin chen rgyal po, succeeded his father to the Yar rgyab throne and took monastic ordination from Chos grags ye shes at the end of his life in 1496 (fire-dragon year). ${ }^{67}$ His younger brother,

61 Lo chen's activities in Yar rgyab are summarized in Ehrhard 2002: 49, 77f., 81-95. The surviving letters from the pen of the translator are reproduced as facsimile images in Ehrhard 2002b. The finely written correspondence contains sixty letters to members of the Yar rgyab court and five letters addressed to Gong dkar ba, who was in charge of the Gong dkar district; cf. Ehrhard 2002: 97.

62 For his renovation and construction activities at Yar rgyab and elsewhere in Lhokha, see, inter alia, Ehrhard 2002: 52, 54, 84 n. 47, 94; Chos grags ye shes, Lochen Biography: 407f., 446; Byang chub rnam rgyal, Jampalingpa Biography: 53a7-b1. Cf. also Jackson in this volume.

63 Cf. Ehrhard 2002: 79. The construction of the great stüpa (mchod rten chen mo) at Byams pa gling is summarized on pp. 83-85. See also the detailed sections dealing with the different stages in the realization of the project in Chos grags ye shes, Lochen Biography: 395-416; and Byang chub rnam rgyal, Jampalingpa Biography: 57b-67b, 69a5-70a7. Lo chen succeeded his deceased teacher as the monastic leader of Byams pa gling and compiled monastic guidelines (bca' yig) for its community; cf. ibid.: 92a2-6.

64 dPa' bo gtsug lag 'phreng ba, Feast for the Learned Ones: 572; Ehrhard 2002: 20f.; Chos grags ye shes, Fourth Shamar Autobiography: 948.

65 The second part of his autobiography covers the years 1474-1506, i.e. Chos grags ye shes, Fourth Shamar Autobiography: 945-996. See also dPa' bo gtsug lag 'phreng ba, Feast for the Learned Ones: 572-585.

66 Chos grags ye shes, Fourth Shamar Autobiography: 948, 949, 963, 965, 967, 971, 972, 976 , 979, 980f. See also dPa' bo gtsug lag 'phreng ba, Feast for the Learned Ones: 572.

67 Chos grags ye shes, Fourth Shamar Autobiography: 977. Having obtained monastic precepts, 
bZhi 'dzom Rin chen don yod (fl. late $15^{\text {th }}$ cent.), was ordained (i.e. bar ma $\mathrm{rab}$ byung) earlier, in $1485 / 86 .{ }^{68}$ Rin chen don yod, who is exclusively addressed with the epithet Kun spangs chen po in the Fourth Zhwa dmar pa's autobiography, received his teacher on several occasions in Yar rgyab and also accompanied him on longer journeys. ${ }^{69}$ A contemporary of Chos grags ye shes who also became a leading lama at the Yar rgyab court in the second half of the fifteenth and early sixteenth centuries was Zhwa lu lo tsā ba Chos skyong bzang po (1441-1527). In the middle part of his life (ca. 1480s-1515), the translator from Zhwa lu seems to have spent extensive periods in Yar rgyab, where he taught at the court of Kun dga' bsod nams rin chen rgyal po and found backing for his extensive writing and translation activities. ${ }^{70}$ Zhwa lu lo tsā ba became the monastic leader at Grwa thang in 1495 (wood-hare year) and settled in Yar rgyab for some years before returning to gTsang for abbatial responsibilities at Zhwa lu. ${ }^{71}$ Zhwa lu lo tsā ba, the Fourth Zhwa dmar pa, and the latter's teacher, Lo chen bSod nams rgya mtsho, were three highly esteemed religious dignitaries of their time. They maintained very close contacts not only with the nobility of Yar rgyab, but also with the central court at sNe gdong and with the other ruling houses all over Central Tibet. Their lifestories reflect their fruitful relationships

he was also addressed by the epithet E wam thams cad mkhyen pa; cf. Rin chen bkra shis, Shalu Lotsawa Biography: 132; dPa' bo gtsug lag 'phreng ba, Feast for the Learned Ones: 581. For this figure, see also Byang chub rnam rgyal, Jampalingpa Biography: 37b6-7 (here Mi'i dbang po chen po Rin chen rgyal po ba), $72 \mathrm{~b} 3$ (here dPon sa Rin chen rgyal po ba); bSod nams grags pa, New Red Annals: 224, 225 (here Rin chen rgyal po); Byang chub dbang rgyal, Gongkarwa Biography I: 172 (here E wam chos kyi rje); and gZhon nu dpal, Blue Annals: 823 (here Rin chen rgyal po), 831 (here Kun dga' rin chen rgyal po). Like the Yar rgyab nobles Gong dkar Kun dga' rnam rgyal and bSod nams 'byung gnas (below), Kun dga' rin chen rgyal po is also addressed with the title of a royal monk (mtho btsun, tho btsun); cf. Chos grags ye shes, Fourth Shamar Autobiography: 979.

68 Chos grags ye shes, Fourth Shamar Autobiography: 965f., 961; dPa' bo gtsug lag 'phreng ba, Feast for the Learned Ones: 577. For this figure, see also Byang chub rnam rgyal, Jampalingpa Biography: 59a7, 72b3; Byang chub dbang rgyal, Gongkarwa Biography I: 168 (here Kun spangs chos kyi rje); and gZhon nu dpal, Blue Annals: 831, 836 (here bSod nams ye shes dpal bzang po).

69 Chos grags ye shes, Fourth Shamar Autobiography: 972, 979, 992. Rin chen don yod alias Kun spangs chen po supported construction work at dGa' ldan ma mo in Kong po and 'Brang rgyas bde can monastery (i.e. Yangs pa can) in sTod lung, northwest of Lhasa; cf. ibid., 974, 995. Several colophons in the writings of Chos grags ye shes convey that his ordination name was bSod nams ye shes dpal bzang po; see Chos grags ye shes, Fourth Shamar Collected Works.

70 For his translation activity in Yar rgyab, see particularly Rin chen bkra shis, Shalu Lotsawa Biography: 128-133, 148. The translations that Zhwa lu lo tsā ba prepared at estates or monastic convents in Yar rgyab include several canonical treatises listed under Tōhoku catalog nos. 1363, 1488, 1906, 2302, 2499, 2540, 3913, 4198, 4279, 4281, 4303, 4421, 4437, 4458.

71 Rin chen bkra shis, Shalu Lotsawa Biography: 140f. With the intention of binding him permanently to the region (phyogs 'dir yun du bzhugs pa ched), Chos skyong bzang po was appointed the abbatial leader of lCags ri monastery in 1493 (ox-year) and Grwa thang in 1495 (wood-hare year); cf. ibid.: 135f. 
with the Yar rgyab family members, who receive prominent mention and deep appreciation in the biographical narratives. Unsurprisingly, their connection to the rulers of Yar rgyab is depicted in line with Tibetan ideas about the unique relationship between a spiritual teacher and a worldly lay ruler. All biographers portray their protagonists in a "priest-patron" (yon mchod; mchod yon) relation with the Yar rgyab rulers. ${ }^{72}$ Through a period of continuous funding, as their lifestories convey, each of them left a considerable impact on the religious landscape of the region. ${ }^{73}$ In this process, the family estates in Dol, Grwa nang and Grwa phyi played a crucial role as places to which the teachers were invited for instruction and ritual, and from which ambitious projects were facilitated and realized.

Byams pa gling pa's biography refers to a group of three Yar rgyab estates (i.e. gzhis kha yar mar gsum; gzhis kha yan phyin gsum) in the context of provisions being regularly supplied for Byams pa gling monastery and for the festivities during the stüpa construction work. ${ }^{74}$ These three estates can be identified as (1) rGyal chen gling and (2) Dar rgyas gling in Grwa nang, and (3) lHun grub gling in Grwa phyi. ${ }^{75}$ In the wider context of the biographies at hand, these three estates in the Grwa region, together with the estate of (4) lHun grub lha rtse in the Dol valley, were the family's main secular foundations that provided material support to visiting lamas and the communities under their direction. Later, in the late fifteenth and early sixteenth centuries, (5) dPal 'byor rab brtan became another important estate of the ruling family in the lower Grwa nang valley.

72 Rin chen bkra shis, Shalu Lotsawa Biography: 133; Chos grags ye shes, Fourth Shamar Autobiography: 994; Chos grags ye shes, Lochen Biography: 408, 456; and Byang chub rnam rgyal, Jampalingpa Biography: 55a1, 68b6, 90a1.

73 Ehrhard observes about Lo chen that "his association with the rulers of Yar-rgyab in the latter part of his life [...] indicates the particular importance of this family in the support of Buddhist institutions in the 1Ho-kha area." Cf. Ehrhard 2002: 97. The influence of the Yar rgyab rulers in the religious domain (chos phyogs) is summed up by g.Yu gra bsod tshe; cf. sDe pa yar rgyab pa'i skor gyi dpyad gleng: 18. Jackson's contribution in this volume exemplarily demonstrates the contribution of this noble house in the area of religious art. The translation of canonical scriptures and printing of books under the patronage of Yar rgyab is only marginally touched upon here (cf. notes 34, 35, 45, 54 and 70); these matters will be examined in a future contribution. See also Jackson 1983, 1989, and Sernesi in this volume.

74 Byang chub rnam rgyal, Jampalingpa Biography, ff. 60b4, 92a6-b1: nang so yab yum pa'i drung gis kyang / de rnams kyi steng du sa zhing 'phar ma [92b] gnang ba dang / snga gong gang yod kyi phyag 'jur/ gzhis kha yan byin (=phyin) gsum nas zhag 'degs mdzad pa/ [...]. A group of three estates (gzhis kha yar mar gsum) is also mentioned by Chos grags ye shes, who draws upon Byams pa gling pa's lifestory for retelling his master's life; cf. Lochen Biography, p. 397: lo re bzhin 'dzugs ston sgang thon ston sogs gzhis kha yar mar gsum nas blos gzhal bar mi spyod pa'i dus ston bzang po rnam bzhag dang bcas pa rje 'di nyid kyi bka' kho na spyi bos nod de bsgrubs pas/las mi thams cad yid gcig tu 'dun pas rtsol ba las/ [...].

75 Byang chub rnam rgyal reports that in the year 1467 (fire-pig), Gong dkar ba travelled to Yar rgyab and visited the three estates of Dar rgyas gling, rGyal chen gling and lHun grub gling to receive religious instructions from Byams pa gling pa; see Jampalingpa Biography: 50a2-3. 


\section{(1) rGyal chen gling}

As mentioned above, the Grwa region constituted the early headquarters of the Yar rgyab pa, with large estate holdings and the family's monastic centres Grwa thang and Byams pa gling in the lower part of Grwa nang. The estate of rGyal chen gling in the central part of the valley had been the residence of Drung chen bZhi 'dzom and remained an important stronghold for the family throughout the fifteenth century. This estate was the birthplace of Gong dkar ba and thus it was also the abode of his influential mother ${ }^{76}$ the Yar rgyab queen rDo rje bde ma, as well as his half-brother bZhi 'dzom Rin chen don yod. ${ }^{77}$ In Gong dkar ba's biography the family palace is mentioned by its full names as rGyal chen rnam thos dga' ba'i gling and dPal rGyal chen gling gi khang bzang. ${ }^{78}$ The former site of the estate can be located in presentday rGyal gling (Ch. Jílín). The origin of the recently restored monastery in the centre of this village can be traced back to one of the "Four Communities" (Tshogs [pa] sde bzhi; var. Jo gdan tshogs pa/sde bzhi) associated with the vinaya lineage (sdom rgyun) of Śākyaśrïbhadra (1127/40s-1225). In the year 1476 (fire-monkey), apparently during the reign of Kun dga' bsod nams rin chen rgyal po of Yar rgyab, the wandering community of the dGe 'dun sgang pa is reported to have found a permanent residence at the estate of rGyal chen gling, thus becoming known as the rGyal gling tshogs pa. ${ }^{79}$

76 Cf. Byang chub dbang rgyal, Gongkarwa Biography I: 18.

77 Cf. Byang chub rnam rgyal, Jampalingpa Biography: 59a7; Chos grags ye shes, Fourth Shamar Autobiography: 979 (here Kun spangs chen po).

78 Byang chub dbang rgyal, Gongkarwa Biography I: 18, 213.

79 Cf. Chos grags ye shes, Lochen Biography, pp. 422f.: skabs der tshogs pa dge 'dun sgang pa la stod phyogs su thegs pas nang du mi 'thun pa dag gis rkyen byas te dge 'dun phal cher gyis/ mkhan chen pas gtsos pa' $i$ 'ga' shes gar 'byon cha ma 'tshal ba la/ yar rgyab nang sor bka' gnang stel dge 'dun gyi sde 'di [423] tsam gsar du 'dzugs par brtsams kyang dka' mo 'ong bas dge 'dun 'du ba'i rkyen sbyor ba rigs shes stsal bas/ bka' bzhin zhabs tog phul/ de'i rjes su mkhan chen sher dpal ba gshegs nas mkhan po'i 'os kyang cher ma 'tshal ba lal sngon du tshogs pa rang gis yig brgya 'bum gter cig mdzod/ de'i rjes su sgrol ma la zan ril phul ba de khyi'u brda ma phrad pa cig len du chug la der gang lung bstan pa de mdzad par rigs pa yin gsung ba'i bka' ma 'ongs pa mngon du ston pa'i tshad mar gyur pa stsal ba nal bka' bzhin 'tshol bas tshogs pa yar 'phel du tshags su chug pa'i bka' dring mdzad/. See also Heimbel 2013: 201, 202. The characteristic shape of the monastery points to its past as a secular foundation; cf. Heimbel 2013: 236, image 1. Natives report that defense walls and a moat surrounded the monastic complex in earlier times; interview, Grwa nang, Tibet, 2015. This corresponds to Byams pa gling pa's poetic description of the family palace; cf. bSod nams rnam rgyal, rGyal chen gling gi 'bum chen dkar chag, f. 3a7-3b1: rgyal chen gong ma'i drin gyis ni/ bsod nams ldan rnams 'du ba'i gling / dpal dang ldan pa'i pho brang ni/ 'chi med grong khyer lta bur mngon/ 'khor ba'i dpal 'byor khang bzangs su/ grags pa'i rnga thug bslang ba bzhin/ 'dod yon me chen 'bar ba'i rtser/mnga' thang du ba'i sprin phung 'thibs/ rnam gsal ra ba dkar po yil phyi rol 'obs kyis bskor ba dag/ma lus srid pa'i snod yangs bzhin// rol rtsed [3b] skye bo skyid pa'i tshal/ ljon shing sngon po'i phreng bas mdzes//. 


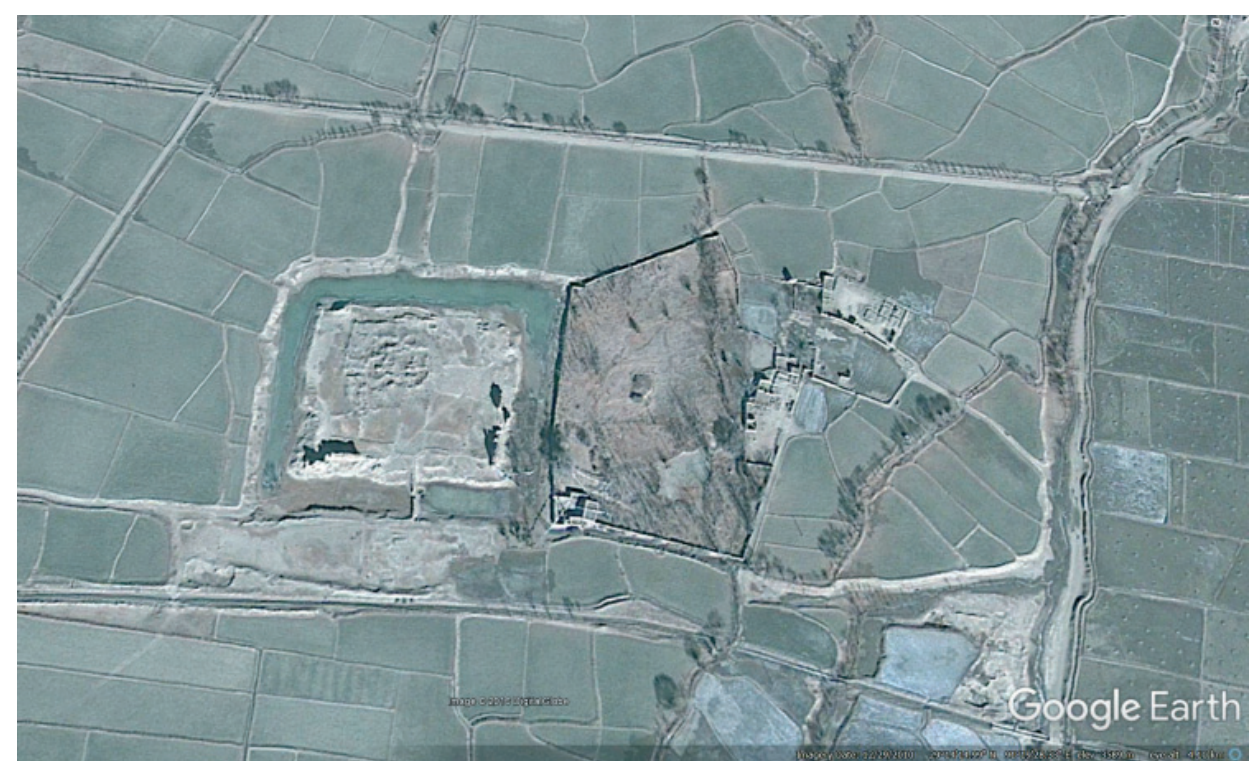

Fig. 5: Satellite image showing the ruins of Dar rgyas gling estate, southwest of Grwa thang monastery (based on Google Earth; Satellite photo 12/2010, Digital Globe).

\section{(2) Dar rgyas gling}

Dar rgyas gling was another large family estate in the Grwa nang valley. According to locals, the remains of an old building going back to the foundation of Dar rgyas gling are found about 1 kilometre southwest of Grwa thang monastery, in the midst of fields in the lower Grwa nang valley. These large ruins, surrounded by traces of fortified walls and a water-filled trench, are said be have been the seat of a former king or ruler (see fig. 5). ${ }^{80}$ Situated close to Byams pa gling, this estate was probably a main force behind the Great Prayer Festival (i.e. smon lam chen mo) and the summer teachings (dbyar chos) hosted annually at the religious centre of the Yar rgyab realm. ${ }^{81}$

80 Interview, Grwa nang, Tibet, 2015. g.Yu gra bsod tshe provides approximate measurements of the ruined site; cf. sDe pa yar rgyab pa'i skor gyi dpyad gleng: $15 \mathrm{f}$.

81 The summer teachings were established by Lo chen on the wish of his deceased master and took place for the first time in 1477 (fire-bird year); cf. Byang chub rnam rgyal, Jampalingpa Biography: 109b; Chos grags ye shes, Lochen Biography: 427. 


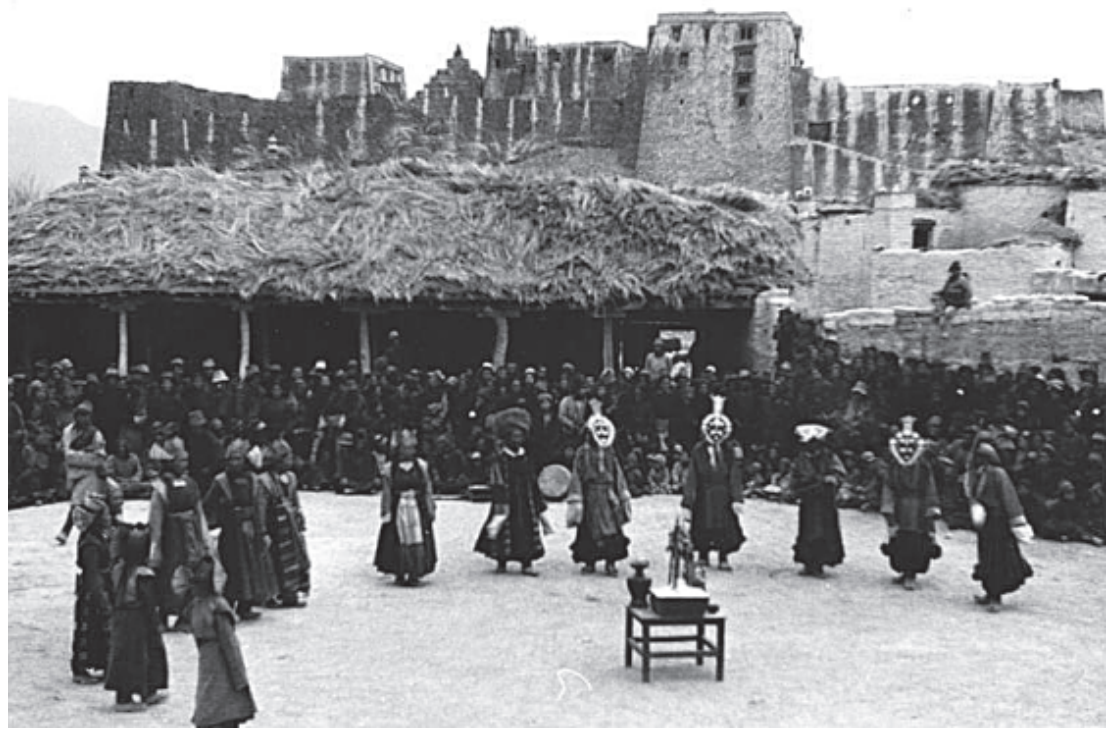

Fig. 6: Ache Lhamo dancers performing in front of the ruined fortress at lCe bde zhol in the lower Dol valley. The old fortress seems to be the former site of the lHun grub lha rtse estate of the Yar rgyab pa (Photo: Ernst Schäfer, April 1939; German Federal Archive, Bild 135-S-15-25-16).

\section{(3) lHun grub gling}

The main seat of the Yar rgyab rulers in the eastern part of their domain was lHun grub gling in the Grwa phyi valley. ${ }^{82}$ This estate to the east of Grwa nang was, for instance, responsible for the provisions supplied on the occasion of Byams pa gling pa's ascent to the throne of gDan sa thel in the year 1464 (wood-monkey). ${ }^{83}$ Fifteen years later, in the summer of 1479 (pig year), Lo chen, being requested by the incumbent dpon chen Kun dga' rin chen dbang gi rgyal po, taught at the court of 1 Hun grub gling. ${ }^{84}$ This Yar rgyab ruler, who became a monk later in life, seems to have been primarily based at lHun grub gling palace in Grwa phyi. ${ }^{85}$ In the vicinity, he maintained a hermitage

82 Sources have revealed that lHun grub gling is not identical with lHun grub lha rtse in the lower Dol valley as was assumed earlier; cf. Ehrhard 2002: 77.

83 The circumstances of his abbatial enthronement at gDan sa thel (var. gDan sa mthil) by the Phag gru ruler Kun dga' legs pa (1433-1482/83) are summarized in Byang chub rnam rgyal, Jampalingpa Biography: 48a2-49a2.

84 Lo chen's teachings to the Yar rgyab ruler and his family are mentioned in Chos grags ye shes, Lochen Biography: 434f.

85 Chos grags ye shes, Fourth Shamar Autobiography: 953 (here yar rgyab dpon chen), 994 (here dpon chen); Rin chen bkra shis, Shalu Lotsawa Biography: 128f. (here mi’i dbang po). 
(dben gnas) called E wam or E wam chos 'khor where he received his principal lamas, the Fourth Zhwa dmar pa and Zhwa lu lo tsā ba. ${ }^{86}$ Since the early fifteenth century lHun grub gling had been a major administrative seat of the Yar rgyab family. Referred to as rGyal sa lHun grub gling gi pho brang or rGyal po'i pho brang lHun grub gling by Byams pa gling pa, ${ }^{87}$ it is probably identical with the "King's Residence [in] Grwa phyi" (grwa phyi rgyal sa) where he spent the break between teaching terms (chos bar) in $1418 / 19 .{ }^{88}$ The exact location of lHun grub gling is uncertain; it is possible that this estate met the same fate as rGyal chen gling in the Grwa nang valley. The abandoned monastery of Tshong 'dus tshogs pa in present-day Tshong 'dus (Ch. Chōng duī) is known as the home of yet another wandering community that followed ascetic practices and preserved the lineage of Śākyaśrībhadra. It was here that the wandering community of the Bye rdzing tshogs pa (var. Byi rdzing tshogs pa) found a permanent residence and became called Tshong 'dus tshogs pa. ${ }^{89}$ The Fourth Zhwa dmar pa attests to their presence at lHun grub gling, where he explained Sāntideva's Bodhicaryāvatāra to the Bye rdzing community in 1486 (fire-sheep year). ${ }^{90}$ About twenty years later, in 1504 (wood-bird year), again at the court of lHun grub gling, he gave the lung transmission of a bKa' brgyud biographical collection ( $b \mathrm{Ka}$ ' rgyud rnam thar gsal ba'i phreng ba) to the family of the present ruler and to the Bye rdzing abbot, whose community may have also been present. ${ }^{91}$

\section{(4) lHun grub lha rtse}

In addition to the group of the three main estates located in Grwa, the family maintained another important estate in the western part of Yar rgyab. The biographies

86 Chos grags ye shes, Fourth Shamar Autobiography: 972 (here dpon chen pa), 979 (here mtho btsun chen po); Rin chen bkra shis, Shalu Lotsawa Biography: 132f., 135, 136.

87 Cf. bSod nams rnam rgyal, rGyal chen gling gi 'bum chen dkar chag: 2b7, $6 \mathrm{b6}$.

88 Byams pa gling pa visited Grwa phyi rgyal sa during the break between teaching terms with a group of students under the guidance of Chen po Blo [gros] 'phel ba from rTse thang in about 1418/19; cf. Byang chub rnam rgyal, Jampalingpa Biography: 9b6-10a3.

89 Cf. Heimbel 2013: 204. See also Sørensen and Hazod 2007: 172 n. 423. As for rGyal chen gling, the architectonical appearance of the Tshong 'dus tshogs pa monastery supports the assumption that the wandering Bye rdzing branch settled in the former residence of a king or ruler; cf. Heimbel 2013: 239, image 3.

90 Chos grags ye shes, Fourth Shamar Autobiography: 967.

91 Ibid.: 994. Another possible location of this early Yar rgyab palace might have been gTsang grong (Ch. Zàngchōng) in the lower Grwa phyi valley. Two stone pillars (rdo rings) used to be found in the small village to the east of Tshong 'dus, about which Charles Bell (1870-1945) was told "that it was nearly chosen by the kings as the site of their capital." Cf. Richardson 1985: 155. I would like to thank Guntram Hazod, who drew my attention to this ancient site. An imperial stelae with a tortoise base and a mchod rten as the finial (cf. ibid.: pl. 15) still exists at gTsang grong; communication with native from Tshong 'dus, WeChat Voice Messenger, December 2016. 
locate this palace, named lHun grub lha rtse, in the lower part of the Dol valley (Dol mda'). ${ }^{92}$ Its original location is probably the site of the old $1 \mathrm{Ce}$ bde zhol Fortress (ICe bde zhol rdzong) that once stood in the centre of present-day lCe bde zhol (Ch. Jiédéxiù) village (see fig. 6). ${ }^{93}$ The Fourth Zhwa dmar pa mentions a monastery called Chos rdzong or 1Hun grub chos rdzong in the immediate vicinity of the lHun grub lha rtse estate, where his teacher gave religious instructions and practiced seclusion ( $s k u$ mtshams) in 1476 (fire-monkey year). ${ }^{94}$ Chos rdzong is most likely the place where 'Gos lo tsā ba finished the compilation of the Blue Annals, ${ }^{95}$ before the preparation of the printing sheets (par yig; i.e. the copying and proofreading the manuscript) was undertaken at lHun grub lha rtse with the funds of the Yar rgyab queen $\mathrm{dPal}$ rDo rje bde ma. ${ }^{96}$ Chos rdzong was probably located to the south of the lHun grub lha rtse palace, on the hill where a dGe lugs pa nunnery of the same name was located until its destruction in the 1950s. ${ }^{97}$

\section{(5) dPal 'byor rab brtan}

For the late fifteenth century, another estate in Grwa nang is recorded as a vital base for the ruling family. Here, at $\mathrm{dPal}$ 'byor rab brtan, the Yar rgyab noble and later ruler (?) mTho btsun bSod nams 'byung gnas took monastic vows from the Fourth Zhwa dmar pa in 1499 (earth-sheep year). ${ }^{98}$ The site of the estate can be located in a western side valley in the lower part of the valley at present-day dPal rab (Ch. Bái ruò). Later

92 Chos grags ye shes, Lochen Biography: 306; Chos grags ye shes, Fourth Shamar Autobiography 951. See also Ehrhard 2002: 22, 26. 1Hun grub lha rtse seems to be identical with the Dol estate (Dol gzhis kha) visited by Zhwa lu lo tsā ba; cf. Rin chen bkra shis, Shalu Lotsawa Biography: 148.

93 The former fortress at 1Ce bde zhol was in ruins when Ernst Schäfer (1910-1992) and his expedition passed through "Dschettäschöh" in April 1939; cf. German Federal Archive, BerlinLichterfelde, R 135/56, Routenbeschreibung: 49f. Another localization of the Yar rgyab palace in the small side valley of $1 \mathrm{Ha}$ rtse (Ch. Lāzī) to the east of Dol was proposed in Sørensen and Hazod 2007: 173 n. 423, 346 fig. 87a.

94 Chos grags ye shes, Lochen Biography: 422; see also Ehrhard 2002: 88.

95 gZhon nu dpal, Blue Annals (Roerich trans.): ii, 1092.

96 gZhon nu dpal, Blue Annals (Roerich trans.): ii, 1090. The actual carving work started in 1481 (iron-ox year) and was completed at the palace of the Bya rulers in dMyal of present-day lHun rtse County (Ch. Lōngzǐ xiàn); cf. ibid. It is also possible that the manufacture of the printing blocks began at the Yar rgyab palace in Dol or that it was partly executed there; see also Ehrhard 2002: 22 n. 17, 30.

97 Interviews, 1Ce bde zhol (Tibet) and Dehradun (India), 2015.

98 Chos grags ye shes, Fourth Shamar Autobiography: 983 (Is bSod nams 'byung gnas addressed here by the name dPal 'byor rab brtan pa?). See also dPa' bo gtsug lag 'phreng ba, Feast for the Learned Ones: 582. The locality is mentioned several times for the period of the late fifteenth and early sixteenth century; cf. Chos grags ye shes, Fourth Shamar Autobiography: 982, 986, 994. See also dPa' bo gtsug lag 'phreng ba, Feast for the Learned Ones: 580, 582; Rin chen bkra shis, Shalu Lotsawa Biography: 137. 
sources report that the estate turned into a Sa skya foundation in the early seventeenth century. sGar chen mThu stobs dbang phyug (1588-1637) of the Sa skya 'khon family was offered this site during his travels through Lhokha and erected a small monastery within the walls of the old Yar rgyab estate. ${ }^{99}$

The biographies describe these family estates as sites of frequent encounters between the protagonists and their donors from the Yar rgyab family. These wealthy bases of the ruling family can be considered the chief resource behind the activities of the various lamas and the monastic institutions in the region. In addition to the regular funding of Byams pa gling through the three main estates in Grwa, Byang chub rnam rgyal informs the reader that the monastic communities of the realm (mnga' zhabs kyi sde dgon) took part in the annual prayer festival at Byams pa gling, ${ }^{100}$ and that the monks performing the funeral rites for the deceased Byams pa gling pa (d. 1475) were from the monasteries based in the family's core territory of Grwa phyi, Grwa nang and Dol (grwa phyi nang dol dang bcas pa'i dge 'dun). ${ }^{101}$ The Fourth Zhwa dmar pa names the monks of the Tshogs pa dGe 'dun sgang (i.e. the rGyal gling tshogs pa), Byams pa gling and 'Tshal min as three of the communities involved in the rites to fulfil Lo chen bSod nams rgya mtsho's (d. 1482) last wishes on behalf of the Yar rgyab court at lHun grub lha rtse. ${ }^{102}$ These communities in the

99 Cf. Kun dga' blo gros, Sa skya'i gdung rabs: 256, 266, 278. See also Kun dga' blo gros, dPal sa skya pa chen po sngags 'chang, f. 678: [...] lhag par yar rgyab dpon sa'i gzhis ka dpal 'byor rab brtan char gtogs bcas gdul zhing du gzigs nas phyogs der gdan phab ste bstan 'gro'i don chen du mas rjes su bzung mthar/ gzugs sku 'od gsal chos dbyings su bsdu bar mdzad pa'i rta mthar (=rnam thar) yang gdan sa der mdzad pa dpal sa skya pa chen po sgar chen mthu stobs dbang phyug rnams kyi snang brnyan byin rlabs kyi gzi 'od 'bar ba gsar bskrun mchod tshogs dang bcas tel sa phyogs de'i bde skyid la ched du dgongs pa'i thugs bskyed dang chabs gcig zangs ri nyung bkra shis rnam rgyal la phebs skabs bsu ba sogs legs lam gyi bka' 'doms dang bcas dpal rab tu stsal/. A local of Grwa nang told me that dPal rab dgon was situated just above Byams pa gling monastery before it relocated to the opposite valley; interview, Grwa nang, Tibet, 2015. Initially located in the monastery's immediate vicinity, the dPal 'byor rab brtan estate might thus be identical with the gZhis ka Byams pa gling to which Zhwa lu lo tsā ba was invited in about 1515 (wood-pig year); cf. Rin chen bkra shis, Shalu Lotsawa Biography: 148.

100 Byang chub rnam rgyal, Jampalingpa Biography: 71a6-7. Also in Chos grags ye shes, Lochen Biography: 408; Ehrhard 2002: 85.

101 Byang chub rnam rgyal, Jampalingpa Biography: 90a4.

102 Cf. Chos grags ye shes, Lochen Biography: 456f. See also Ehrhard 2002: 95; dPa' bo gtsug lag 'phreng ba, Feast for the Learned Ones: 575. 'Tshal min (var. Tshal min; mTshal min) in the Dol valley was another important monastery of the Yar rgyab pa. Its founding goes back to the Jo nang master sNyag phu ba bSod nams bzang po (1341-1433), also known just as 'Tshal min pa, who was also associated with the dGe 'dun sgang branch of the Four Communities (Tshogs [pa] sde bzhi) holding up Śākyaśrî’s tradition; cf. Yon tan bzang po, Tshalminpa Biography: 267.2-6; see also Heimbel 2013: 215f. Later sources elaborate that the Fifth Karma pa De bzhin gshegs pa (1384-1415) offered this site to bSod nams bzang po, from whom he had requested monastic ordination; cf. ibid.: 215. One of bSod nams bzang po's main disciples was 'Phags chen bSod nams dar, who is said to have been born in in[to? the family of] Yar rgyab; cf. dGe 
heartland of Yar rgyab enjoyed occasional or regular funding from one or the other estate in the vicinity (see fig. 4). Lo chen was repeatedly involved in renovation and construction work at various monastic sites, including 'Tshal min in Dol and Grwa thang in Lower Grwa nang. ${ }^{103}$ It is clear that material and financial means needed for such costly undertakings were not only assembled by the local population, but were also realized through the royal patronage of the local court.

\section{Territorial Boundaries}

Influence of the Yar rgyab rulers beyond the central valleys of Dol, Grwa nang and Grwa phyi can also be seen in the lifestories of their court lamas. The biographies mention the presence of the ruling family also on the northern banks of the gTsang po river, including parts of present-day sGrags and 'Phrang 'go (var. 'Phrang mgo, sgo, po; 'Phreng mgo, sgo). Byang chub rnam rgyal, for instance, states that the area of mTsho rgyal gling, which can probably be located at present-day mTsho rgyas gling (Ch. Cuòjiélín) in the lower part of sGrags, was under the Yar rgyab rulers before it fell into the hands of the sNel pa family. ${ }^{104}$ In line with this, the Fourth Zhwa dmar pa recounts in his autobiography that in the year 1501 (iron-bird) his patron escorted him to Lower 'Phrang po ('Phrang po mda') and mKhar chu on the other side of the gTsang po. Here, in Lower sGrags (sBra mda'), the Zhwa dmar incarnate gave teachings to dPon chen mTho btsun and his brother. ${ }^{105}$ Earlier, in 1478 (earth-dog year), another Yar rgyab ruler had welcomed him in the far south of the family's central valleys. Chos grags ye shes gave the lung transmission for the Six Doctrines of Nāropa to the court of the ruler at sGa 'dra (Ch. Gānzhā) in eastern Yar

ye Tshul khrims seng ge, rGya bod kyi chos 'byung rin po che, f. 29a5-6: dge 'dun sgang ba' $i$ mkhan chen mtshan (=mtshal) min pa bsod nams bzang po//de'i slob ma yar rgyab tu 'khrungs pa 'phags chen bsod nams dar/ de'i dbon po dang / dbu mdzad nas gyis so/. From among his followers, the four so-called 'Phags sde communities ('Phags sde bzhi) were formed; cf. dPa' bo gtsug lag 'phreng ba, Feast for the Learned Ones: 262; see also Heimbel 2013: 215 n. 156. The Yar rgyab pa must have been among bSod nams bzang po's main devotees and patrons in the latter part of his life; cf. also Sørensen and Hazod 2007: 175 n. 423 and g.Yu gra bsod tshe 2016: 13. Lo chen rejected the abbatial throne of 'Tshal min that was offered to him by the Yar rgyab officials (nang so rnam pa); cf. Chos grags ye shes, Lochen Biography: 379 (here Tshal min); Ehrhard 2002: 78. The monastery turned into a dGe lugs pa institution under the Fifth Dalai Lama, whereupon it became known under the name gSung rab gling; cf. Sangs rgyas rgya mtsho, Ganden Religious History: 397 (here Tshal ming [sic!]).

103 Cf. Chos grags ye shes, Lochen Biography: 446; see also note 62 above.

104 Byang chub rnam rgyal, Jampalingpa Biography: 31a5-7; see also ibid.: 24a5-6 (here sGrags kyi 'tsho rgyal gling).

105 Chos grags ye shes, Fourth Shamar Autobiography: 987f.; and dPa' bo gtsug lag 'phreng ba, Feast for the Learned Ones: 583 (here sBrags mda'). This reference seems to be to the Yar rgyab dpon chen mTho btsun bSod nams 'byung gnas. 
'brog and continued his journey towards 1 Ho brag. ${ }^{106}$ Finally, we may also wonder about the castle of Mon mkhar rNam sras gling (var. Mon dga' rnam sras gling) and its administrative status at that time. According to Byang chub rnam rgyal's sketch of the Yar rgyab territorial boundaries, the old Phag mo gru pa estate in present-day rNam sras gling village (Ch. Lăng sài lǐng cūn), in a side-valley to the east of Grwa, was part of the greater family domain. ${ }^{107}$ Yet this and other questions must be left for future investigations of this ruling house and their obviously very important role throughout the fifteenth century.

As a major political power under the successive dynasties of the Phag mo gru pa and the Rin spungs pa, the Yar rgyab pa's territory at the heart of Central Tibet became a vital centre for the intellectual and cultural accomplishments of the time, embedded in a transregional network of powerful ruling houses and esteemed lamas travelling the country. In the biographies of their preceptors, the rulers of Yar rgyab take a prominent role as exclusive disciples and major patrons. The authors must have had the local court in mind when compiling these lifestories in which they provide crucial historic details about the ruling family and their generous financial backing. According to the narrative logic of such texts, the unique relationship between representatives of the religious and the temporal spheres is what allows the protagonists' beneficent activities in the realm of their donors. On the other hand, the royal patronage implemented through the orders of proficient lamas, likewise produces great virtue on the side of the ruling family. ${ }^{108}$ Hence, Byang chub rnam rgyal recounts that in the year 1469 (earth-ox), as a result of sponsoring the copying of two large text collections at Zhal phu in Dol, the political power (chab srid) of the patron(s) from Yar rgyab increased, and that the region experienced excellent harvest and its people happiness (bde skyid). ${ }^{109}$

106 Chos grags ye shes, Fourth Shamar Autobiography: 951. This reference seems to be to the Yar rgyab ruler Rin chen don yod. Lo chen had also been received by Rin chen don yod at sGa 'dra; cf. Chos grags ye shes, Lochen Biography: 389; Ehrhard 2002: 81. For sGa 'dra, see also Sørensen and Hazod 2007: 170 n. 421.

107 As in note 12 above. For the year 1438 (earth-horse) Byang chub rnam rgyal reports a meeting (mjal 'dzom) at Mon mkhar rNam sras gling between the sNe gdong ruler, together with his court officials, and the ruling elite from Yar rgyab together with the Che sa Sangs rgyas rgyal mtshan, who was in exile at that time; cf. Jampalingpa Biography: 25a6-5.

108 See, for example, Byang chub rnam rgyal, Jampalingpa Biography: 53b3-4.

109 See Byang chub rnam rgyal, Jampalingpa Biography, 51b7-52a1: de ltar rgyud 'bum bzhengs pa 'di dang / lo snga ma la mdo mangs bzhengs pa 'di'i byin rlabs kyis/ spyir gyis sbyin bdag chen po'i chab srid dar zhang (=zhing) rgyas pa dang / bye brag tu yang zhal phu [52a] lung par lo legs shing 'ongs che ba byung ba'i grags pa shin tu che la/ yul mi de dag kyang bde skyid dang ldan pa byung ba kun gyi mthun snang du grub pa yin no/. 


\section{Bibliography}

Tibetan Sources:

'Brug pa kun legs. Autobiography Drukpa Künleg = 'Brug pa kun legs kyi rnam thar. lHa sa: Bod ljongs mi dmangs dpe skrun khang, 2005.

bSod nams grags pa, Pạ chen. New Red Annals = rGyal rabs 'phrul gyi lde mig gam deb ther dmar po'am deb gsar ma. Giuseppe Tucci (ed./trans.). Deb t'er dmar po gsar ma: Tibetan Chronicles by bSod nams grags pa. Roma: Istituto Italiano per il Medio ed Estremo Oriente, 1971.

bSod nams rnam rgyal, Byams pa gling pa. rGyal chen gling gi 'bum chen dkar chag [written in 1430]. dbu med ms., 1a-6b. Courtesy of Tashi Tsering (Amnye Machen Institute, Dharamsala).

Byang chub dbang rgyal, rGya ston. Gongkarwa Biography I = rDzong pa kun dga' rnam rgyal gyi rnam thar. bSlab gsum rgyal mtshan (ed.). 1Ha sa: Shang kang then ma dpe skrun khang, 2001.

Byang chub rgyal mtshan, Ta'i si tu. Po ti bse ru=Rlangs kyi po ti bse ru rgyas pa. 1Ha sa: Bod ljongs mi dmangs dpe skrun khang, 1986.

Byang chub rnam rgyal dge legs, lCags ri ba. Jampalingpa Biography $=$ dPal byams pa gling pa'i rnam par thar pa ngo mtshar phreng ba. dbu med ms., C.P.N. cat. no. 002775(1), 1a-95a.

Chos grags ye shes (=Fourth Zhwa dmar). Fourth Shamar Autobiography = rTogs pa brjod pa'i tshigs su bcad pa utpa la'i phreng ba. In Fourth Shamar Collected Works, vol. 6, 931-996.

Gö Lotsawa Biography = dPal ldan bla ma dam pa mkhan chen thams cad mkhyen pa don gyi slad du mtshan nas smos te gzhon nu dpal gyi rnam par thar pa yon tan rin po che mchog tu rgyas pa'i ljon pa. Pe cin: Mi rigs dpe skrun khang, 2004.

Fourth Shamar Collected Works = Thams cad mkhyen pa zhwa dmar bzhi pa spyan snga chos kyi grags pa'i gsung 'bum. 6 vols. Pe cin: Krung go'i bod rig pa dpe skrun khang, 2009.

Lochen Biography = rJe thams cad mkhyen pa lo tsä ba chen po'i rnam par thar pa ngo mtshar rgya mtsho. In Fourth Shamar Collected Works, vol. 4, 272-458.

Chos 'phel. 2004. Gangs can bod kyi gnas bshad lam yig gsar ma/ lha sa khul gyi gnas yig. Pe cin: Mi rigs dpe skrun khang.

dGe slong Blo bzang don ldan. 1982. "Thon mi sam bho ța'i rnam thar rgan rabs ngag rgyun." gTam tshogs 1982/1: 3-7.

$\mathrm{dPa}$ ' bo gtsug lag 'phreng ba. Feast for the Learned Ones = Chos 'byung mkhas pa' $i$ dga' ston. Pe cin: Mi rigs dpe skrun khang, 2006.

$\mathrm{dPal}$ brtsegs bod yig dpe rnying zhib 'jug khang (ed.). 2013. Brief Introduction to the History of Tibetan Printing Technology = Bod kyi shing spar lag rtsal gyi byung rim mdor bsdus. 1 Ha sa: Bod ljongs bod yig dpe rnying dpe skrun khang. 
Grags pa rdo rje, Shākya dGe slong. mKhan rgyud rnam gsum byon tshul gyi rnam thar. dbu med ms., C.P.N. cat. no. 002775(6), 1a-25b.

g.Yu gra bsod tshe. 2016. "sDe pa yar rgyab pa'i skor gyi dpyad gleng «thon rigs kyi lo rgyus skor gleng ba» zhes par lung sbyor bgro gleng gi tshul du." Bod ljongs zhib 'jug 2016/1: 11-22.

gZhon nu dpal, 'Gos lo tsā ba. Blue Annals. George N. Roerich (trans.). The Blue Annals. Reprint. Delhi: Motilal Banarsidass, 1979.

Kun dga' blo gros, Ngag dbang. dPal sa skya pa chen po sngags 'chang bla ma thams cad mkhyen pa ngag dbang kun dga' blo gros sangs rgyas bstan pa'i rgyal mtshan dpal bzang po'i rtogs pa brjod pa ngo mtshar 'phrul gyi rol rtsed sde bzhi' $i$ 'byung gnas. In Lam 'bras slob bśad: The Sa-skya-pa Teachings of the Path and the Fruit, According to the Tshar-pa Transmission. Sa-skya Lam-'bras Literature Series. Dehra dun, U.P.: Sakya Centre, 1983, vol. 6, 301-715.

Sa skya’i gdung rabs ngo mtshar bang mdzod kyi kha skong. Pe cin: Mi rigs dpe skrun khang, 1991.

Ngag dbang thub bstan. 2014. History of Namrab Thongmön Dagpo Dratshang Monastery = rNam rab mthong smon dwags po grwa tshang gi lo rgyus. Pe cin: Mi rigs dpe skrun khang.

Nor brang o rgyan. 2006. Nor brang o rgyan gyi gsung rtsom phyogs btus. Pe cin: Krung go'i bod rig pa dpe skrun khang.

Pho brang po ta la dpe rnying bsdu sgrig khang (ed.). 2015. Pho brang po ta lar bzhugs su gsol ba'i dpal ldan sa skya'i gsung rab rnams kyi dkar chag. 1Ha sa: Bod ljongs mi dmangs dpe skrun khang.

rNam rgyal mgon po. Gongkarwa Biography $I I=$ Chos kyi rje thams cad mkhyen pa rdo rje gdan pa chen po'i rnam par thar pa rin po che'i 'phreng pa. dbu med ms., Drepung cat. no. $017059,1 \mathrm{a}-7 \mathrm{~b}$.

Sangs rgyas rgya mtsho, sDe srid. Ganden Religious History = dPal mnyam med ri bo dga' ldan pa'i bstan pa zhwa ser cod pan 'chang ba'i ring lugs chos thams cad kyi rtsa ba gsal bar byed pa baidū rya ser po'i me long. Pe cin: Krung go bod kyi shes rig dpe skrun khang, 1989.

Shākya mchog ldan, gSer mdog pạ chen. Chos kyi 'khor lo bskor ba'i rnam gzhag ji ltar 'grub pa'i yi ge gzu bor gnas pa'i mdzangs pa dga' byed. In The Complete Work (Gsuñ 'bum) of Gser-mdog Pan-chen Śäkya-mchog-ldan. 24 vols. Thimphu: Kunzang Tobgey, 1975, vol. 16, 457-482.

Rongtön Biography = rJe btsun thams cad mkhyen pa'i bshes gnyen shākya rgyal mtshan dpal bzang po'i zhal snga nas kyi rnam par thar pa ngo mtshar dad pa'i rol mtsho. In The Complete Work (Gsun 'bum) of Gser-mdog Pan-chen Śākya-mchog-ldan. 24 vols. Thimphu: Kunzang Tobgey, 1975, vol. 16, 299-377.

Rin chen bkra shis, sKyogs ston. Shalu Lotsawa Biography = rJe btsun zha lu lo tsā ba'i rnam par thar pa brjed byang nor bu'i 'khri shing. Dehradun: Sakya College, 2007, 97-162. 
Tshul khrims seng ge, dGe ye. rGya bod kyi chos 'byung rin po che. Khetsün, Shiníchiro Miyake, Maho Iuchi and Shoko Mekata (eds.). History of Indo-Tibetan Buddhism by dGe ye Tshul khrims seng ge: A Critical and Facsimile Edition of the Tibetan Text with Summary and Index(ゲイェ・ツルティム・センゲ『インド・チ ベット仏教史』：校訂テキストおよび影印）。Tokyo：Otani University Shin Buddhist Comprehensive Research Institute, 2007.

U yon lhan khang (ed.). 2000. History and Cultural Relics of Lhasa vol. 9, Nyemo District = Grong khyer lha sa'i lo rgyus rig gnas deb dgu pa sNye mo rdzong. $1 \mathrm{Ha}$ sa: Grong khyer lha sa srid gros lo rgyus rig gnas dpyad yig rgyu cha rtsom 'bri.

Yangs gling rdo rje. 2003. Si khron bod rig pa'i zhib 'jug deb drug pa. [Khreng tu'u]: Si khron mi rigs dpe skrun khang.

Yon tan bzang po [author name illegible in colophon; cf. p. 296.4], dKa' bzhi 'dzin pa. Tshalminpa Biography = dPal ldan bla ma rin po che bsod nams bzang po la rnam thar gyi sgo nas stod (=bstod) pa dngos grub kyi char gnas. dbu med ms., $40 \mathrm{ff}$. In dPal brtsegs bod yig dpe rnying zhib 'jug khang (ed.). Bod kyi lo rgyus rnam thar phyogs bsgrigs. Zi ling: mTsho sngon mi rigs dpe skrun khang, 2011, vol. 54 (yi), pp. 215-296.

\section{Secondary Sources:}

Ahmad, Zahiruddin. 1995. A History of Tibet by the Fifth Dalai Lama of Tibet. Bloomington: Indiana University, Research Institute for Inner Asian Studies.

Czaja, Olaf. 2013. Medieval Rule in Tibet: The Rlangs Clan and the Political and Religious History of the Ruling House of Phag mo gru pa. With a Study of the Monastic Art of Gdan sa mthil. Wien: Verlag der Österreichischen Akademie der Wissenschaften.

Ehrhard, Franz-Karl. 2002. Life and Travels of Lo-chen bSod-nams rgya-mtsho. Lumbini: Lumbini International Research Institute.

2002b. A Buddhist Correspondence: The Letters of Lo-chen bSod-nams rgyamtsho. Lumbini: Lumbini International Research Institute.

Everding, Karl-Heinz. 2013. "GYANTSE1440. Der Steuerbefreiungserlass (darrgan) des rGyal rtse-Fürsten Rab brtan kun bzang 'phags aus dem Jahre 1440 in Edition, Übersetzung und Analyse." Zentralasiatische Studien 42: 219-317.

Fermer, Mathias. 2010. "The Life and Works of Gong dkar rDo rje gdan pa Kun dga' rnam rgyal (1432-1496)." Unpublished MA thesis (slightly revised), Department of Indian and Tibetan Studies, University of Hamburg.

German Federal Archive (Deutsches Bundesarchiv). Routenbeschreibung [Descriptive Itinerary of the German SS-Tibet Expedition]. Typewritten document of 57 pages (fols. 165073-165130), Files of the Ernst Schäfer Tibet Expedition 1938/39, Abteilung Schriftgut, Berlin-Lichterfelde, Bestandssignatur R 135/56.

Hazod, Guntram. 2009. "Imperial Central Tibet: An Annotated Cartographical Survey of its Territorial Divisions and Key Political Sites." In Brandon Dotson. 
The Old Tibetan Annals: An Annotated Translation of Tibet's First History. With an Annotated Cartographical Documentation by Guntram Hazod. Wien: Verlag der Österreichischen Akademie der Wissenschaften, 161-231.

2010. Geschichte in der Landschaft: Zur historisch-anthropologischen Forschung in Tibet. Habilitationsvortrag an der Universität Wien vom 12.1.2010. AAS Working Papers in Social Anthropology, vol. 12. http://hw.oeaw.ac. at/0xc1aa500e_0x0022e083.pdf (accessed: 2016.10.05)

Heimbel, Jörg. 2013. "The Jo gdan tshogs sde bzhi: An Investigation into the History of the Four Monastic Communities in Śākyaśrībhadra's Vinaya Tradition.” In Franz-Karl Ehrhard and Petra Maurer (eds.). Nepalica-Tibetica: Festgabe for Christoph Cüppers. Andiast: International Institute for Tibetan and Buddhist Studies, vol. 1, 187-242.

Jackson, David. 1983. "Notes on Two Early Printed Editions of Sa-skya-pa Works." The Tibet Journal 8/2: 3-24.

(in collaboration with Shunzo Onoda). 1988. Rong-ston on the Prajñāpāramitā Philosophy of the Abhisamayālamkāra: His Sub-commentary on Haribhadra's 'Sphuțārthā'. Kyoto: Nagata Bunshodo.

1989. "More on the Old dGa'-ldan and Gong-dkar-ba Xylographic Editions." Studies in Central and East Asian Religions 2: 1-18.

2015. "Branch Monasteries of Gong dkar Dorjeden and Phenpo Nalendra, Two Sakya Convents in Central Tibet." In Olaf Czaja and Guntram Hazod (eds.). The Illuminating Mirror: Tibetan Studies in Honour of Per K. Sørensen on the Occasion of his $65^{\text {th }}$ Birthday. Wiesbaden: Dr. Ludwig Reichert Verlag, 244-252. Richardson, Hugh. 1985. A Corpus of Early Tibetan Inscriptions. Hertford: Royal Asiatic Society.

van Schaik, Sam. 2011. "A New Look at the Tibetan Invention of Writing." In Yoshiro Imaeda, Matthew T. Kapstein and Tsuguhito Takeuchi (eds.). New Studies of the Old Tibetan Documents: Philology, History and Religion. Tokyo: Tokyo University of Foreign Studies, 45-96.

Sørensen, Per. 1994. The Mirror Illuminating the Royal Genealogies: Tibetan Buddhist Historiography. An Annotated Translation of the XIVth Century Tibetan Chronicle: rGyal-rabs gsal-ba'i me-long. Wiesbaden: Otto Harrassowitz.

Sørensen, Per and Guntram Hazod (in cooperation with Tsering Gyalbo). 2007. Rulers on the Celestial Plain: Ecclesiastic and Secular Hegemony in Medieval Tibet. A Study of Tshal Gung-thang. Wien: Verlag der Österreichischen Akademie der Wissenschaften.

Stearns, Cyrus. 2007. King of the Empty Plain: The Tibetan Iron-Bridge Builder Tangtong Gyalpo. Ithaca: Snow Lion Publications. 